\title{
Transforming EU Equality Law? On Disruptive Narratives and False Dichotomies
}

\author{
Raphaële Xenidis
}

\begin{abstract}
With the adoption of the Race Equality Directive (2000/43/EC), the Framework Directive (2000/78/EC) and the Gender Directive on goods and services (2004/113/EC) and their subsequent interpretation by the Court of Justice, the landscape of EU non-discrimination law changed dramatically. Beyond this legal evolution, an important discursive shift contemporaneously reframed equality as a genuine fundamental right, in opposition to its historical function as a catalyst for market integration. The aim of this article is to critically interrogate what has been presented as the normative transformation of EU equality law in the aftermath of the 2000s. The present article deconstructs this disruptive narrative and contests the conventionally assumed radical dichotomy between market integration and human rights as overarching rationales for the Union's commitment to equality. It explores the tension between an ambitious fundamental rights rhetoric and the pragmatic fluctuations of the substance of the principle of equality in EU law. It argues that the 'new' post-Amsterdam language of rights, under the guise of 'progress', covers an actual continuity in the normative grammar of EU non-discrimination law. Arguably, the very normative indeterminacy of equality facilitated its exploitation by different EU actors to advance their own strategic aims. This resulted in a form of hybridity of the principle of nondiscrimination, with important consequences in terms of enforceable equality rights and their hierarchy. The demonstration offered here operates at three different levels: the analysis successively focuses on the material and discursive substance of equality, its normative foundations and its operationalization in order to explore the question of the transformation of EU equality law beyond disruptive narratives and false dichotomies.
\end{abstract}

\section{Introduction}

Almost two decades ago, pivotal reforms attracted much attention and brought about important advancements to the field of equality law in the European Union (EU). ${ }^{1}$ Beyond their obvious legal contribution, these reforms also entailed important discursive changes. They decisively reframed what had originally been conceived as an instrument to advance market integration, the principle of non-discrimination, through a relatively new rhetoric of equality as a human right. Thereby, the declared ambition was to reshape the normative underpinnings of EU non-discrimination law.

This evolution in the legal rhetoric matched a blossoming political discourse on the Union's role as a guardian of fundamental and human rights which is still topical today. In his 2017 State of the Union speech, Jean-Claude Juncker emphasized the centrality of the principle of equality for Union law²:

1 Council Directive 2000/43/EC of 29 June 2000 implementing the principle of equal treatment between persons irrespective of racial or ethnic origin [2000] OJ L180/22; Council Directive 2000/78/EC of 27 November 2000 establishing a general framework for equal treatment in employment and occupation [2000] OJ L303/16; Council Directive 2004/113/EC of 13 December 2004 implementing the principle of equal treatment between men and women in the access to and supply of goods and services [2004] OJ L373/37.

See also Directive 2006/54/EC of the European Parliament and of the Council of 5 July 2006 on the implementation of the principle of equal opportunities and equal treatment of men and women in matters of employment and occupation (recast) [2006] OJ L204/23 and Directive 2010/41/EU of the European Parliament and of the Council of 7 July 2010 on the application of the principle of equal treatment between men and women engaged in an activity in a self-employed capacity and repealing Council Directive 86/613/EEC [2010] OJ L180/1.

${ }^{2}$ Jean-Claude Juncker, President of the EU Commission, State of the Union 2017 (Brussels, 13 September 2017). 
Europe must be a Union of equality.

In a Union of equals, there can be no second-class citizens.

In a Union of equals, there can be no second-class workers.

In a Union of equals, there can be no second-class consumers.

With the reforms of the 2000s, the principle of non-discrimination in fact imposed itself on new sets of social interactions as its scope of protection enlarged. Some authors have concluded to the acquisition by the principle of equality of a new 'transformative' function. ${ }^{3}$

Despite what can be called a revolution, today the European corpus of nondiscrimination norms remains both fragmented and contested. On the one hand, the comprehensive reform expected to harmonize the scope of the principle of non-discrimination for all Europeans has been under discussion at the Council for the last ten years. ${ }^{4}$ This legislative stagnation perpetuates the fragmentation of the body of rules prohibiting discrimination. On the other hand, decisive breakthroughs in the jurisprudence of the Court of Justice of the European Union (hereinafter 'CJEU' or 'the Court') sparked strong criticism and resistance, casting doubts on the status of equality as a fundamental value of EU law. Hence, equality as a core structuring principle of society so far remains a piecemeal.

The aim of this article is therefore to critically interrogate the normative transformation of the principle of equality in EU law since the 2000s. It explores the tension between an ambitious fundamental rights rhetoric and the pragmatic fluctuations of the substance of the principle of equality in EU law. To this end, the paper deconstructs the disruptive narrative of a metamorphosis of equality from an instrumental catalyst for market integration into a genuine human right. It contests the conventionally assumed radical dichotomy between market integration and human rights as overarching rationales for the Union's commitment to equality. ${ }^{5}$ Instead, the argument is that the 'new' post-Amsterdam language of rights, under the guise of 'progress', covers an actual continuity in the normative grammar of EU non-discrimination law. Arguably, the very normative indeterminacy of equality facilitated its exploitation by different actors of the EU to advance their own strategic aims. ${ }^{6}$ This resulted in a form of hybridity of the principle of equality.

The demonstration operates at three different levels and successively focuses on the material and discursive substance of equality, its normative foundations and its operationalization. First, the article explores the substantive and discursive construction of the post-2000s EU equality regime. It reviews the efforts of the European legislator and the CJEU to advance equality as a socially structuring principle. It shows how EU institutions, the Court, and the civil society have been juggling with the normative foundations of the principle of non-discrimination in order to pragmatically advance its status and function in EU law (Section II). The following section examines the normative underpinnings of the principle of equality. It explores the discrepancy between the

3 See Elise Muir, 'The Transformative Function of EU Equality Law' (2013) 5 European Review of Private Law.

4 Communication from the Commission to the European Parliament, the Council, the European Economic and Social Committee and the Committee of the Regions COM/2008/0426 final on a Proposal for a Council Directive on implementing the principle of equal treatment between persons irrespective of religion or belief, disability, age or sexual orientation SEC(2008) 2172 [2008] OJ C303/21 (hereinafter the 'Horizontal Proposal' or the 'Proposal').

5 See Mark Bell, Anti-Discrimination Law and the European Union (Oxford: Oxford University Press, 2002), 1-3 and 6-31.

${ }^{6}$ See Peter Westen, ‘The Empty Idea of Equality’ (1982) 95 Harvard Law Review 3. 
grand narrative of a transformation of equality as a fundamental human right and the pragmatism displayed by EU institutions (Section III). It takes a closer look at the cognitive dissonance created by the coexistence of apparently diverging normative frames, as well as their accommodation in what has become a deeply hybrid principle. The final section scrutinizes the consequences for the practical operation of equality. It investigates how the very hybridity of the non-discrimination principle led to a double hierarchy of equality protection, which limits the transformative reach of equality as a socially structuring principle in the EU (Section IV).

\section{The incomplete mutation of non-discrimination into a transformative general principle}

Since the comprehensive reforms of the 2000s, the landscape of EU non-discrimination law has changed completely. This section examines how the terms of the equality debate in EU law have been reset. Ambitioning to shape non-discrimination into a fundamental right which could constitute at the same time a structuring principle of the community, the EU legislator (sub-section A), together with EU civil society, and the CJEU (sub-section B) stretched the scope and application of equality.

\section{A. A triple motion towards a right to equality 'in all areas of life'?}

Re-tracing the evolution of the principle of equality in EU law reveals a triple motion which changed the scope of the principle (i), its language (ii) and its effect (iii).

\section{(i) Towards an extensive principle: broadening and deepening equality}

The history of the transformation of the non-discrimination principle started with the battle for equal pay in the middle of the $1970 \mathrm{~s}^{7}{ }^{7}$ The CJEU's activism at the time of Defrenne II triggered a long transformation process. The reformative movement amplified and later found expression in the important legislative changes of the 2000s. ${ }^{8}$ These reforms codified the CJEU's case law, opened new pathways, and modernized the field of EU equality law. ${ }^{9}$ EU non-discrimination law became subjected to a triple motion: one of broadening with the expansion of the equality protection to new grounds beyond sex and nationality; one of deepening by expanding the scope of the principle itself; but also one of anchoring equality within the language of rights. The purpose was to give equality the general traits of a human right.

To briefly retrace the expansion of EU anti-discrimination law, two major pieces of legislation were passed in 2000: the Race Equality Directive and the Framework Equality Directive. ${ }^{10}$ The main actors behind this change were of two kinds. On the one hand, strongly mobilized civil society organizations pushed for encompassing reforms of the Treaty and

\footnotetext{
7 C-43/75, Gabrielle Defrenne v Société anonyme belge de navigation aérienne Sabena (no. 2)

EU:C:1976:56, [1976] ECR 455. Defrenne II is the landmark case that has established the horizontal direct effect of the principle of gender equality contained in Article 157 TFEU (ex-Art. 141 TEC).
}

8 See $n 1$.

9 See $\mathrm{n} 1$ and Council Directive 2010/18/EU of 8 March 2010 implementing the revised Framework Agreement on parental leave concluded by BUSINESSEUROPE, UEAPME, CEEP, and ETUC and repealing Directive 96/34/EC [2010] OJ L 68/13.

10 See $n 1$. 
legislation. ${ }^{11}$ On the other, EU policy makers, notably the Commission, were amenable to a strengthening of the equality principle. As a result, the Race Equality Directive extended the principle of equal treatment to race and ethnic origin in the fields of employment and vocational training, membership of a professional organization, social protection, including social security and health care, social advantages, education, and the access to and supply of goods and services including housing. ${ }^{12}$ The scope of the directive is wide, affording the broadest protection against discrimination in the EU so far, to many essential fields of everyday life in both the private and the public sectors. In parallel, the Framework Equality Directive extended the principle of equal treatment to the grounds of religion or belief, disability, age, and sexual orientation, but in the field of employment and vocational training only. Hence, from 2000 onwards the number of grounds protected evolved from two to seven, and the areas regulated extended beyond employment, thus broadening and deepening equality protection. ${ }^{13}$

The scope of protection against sex discrimination expanded too. In the aftermath of the two 2000 directives, the debate on gender equality was revived and legislative amendments subsequently codified the jurisprudence of the CJEU. Directive 2002/73/EC amended the previous Directive 76/207/EEC promoting equal treatment for men and women in the field of employment, notably by including definitions of direct and indirect discrimination, thus enhancing the protection. ${ }^{14}$ Most importantly, Directive 2004/113 EC deepened the scope of the principle of gender equality by applying the protection to the access to, and supply of, goods and services. ${ }^{15}$ In 2006 , Directive 2006/54/EC ${ }^{16}$ modernized and simplified the application of the principle of equal treatment on the basis of sex. Directive 2010/41/EC ${ }^{17}$ followed, with the same purpose in the field of selfemployment. By deepening the scope of the existing protection, the EU sought to strengthen its corpus of equality norms and to harmonize the coverage across 'historic' and 'new' grounds.

\section{(ii) Changing the parameters of the non-discrimination debate: crafting a fundamental right}

Beyond the double motion of broadening and deepening non-discrimination law, a third movement consisted in anchoring non-discrimination law within the framework of fundamental rights. This change started after the Maastricht Treaty, with a preliminary liberation from market

11 Crucial transnational stakeholders were for instance the Starting Line Group for the Race Equality Directive. See I Chopin and J Niessen, Proposals for Legislative Measures to Combat Racism and Promote Equal Rights in the European Union (Brussels: Commission for Racial Equality and the Starting Line Group, 1998).

12 This could potentially include the media and advertising when understood as services, as they are not explicitly excluded from the directive, contrary to the Gender Goods and Services Directive 2004/113/EC.

13 This includes nationality.

14 Directive 2002/73/EC of the European Parliament and of the Council of 23 September 2002 amending Council Directive 76/207/EEC on the implementation of the principle of equal treatment for men and women as regards access to employment, vocational training and promotion, and working conditions [2002] OJ L269/15.

15 Directive 2004/113/EC (n 1).

16 Directive 2006/54/EC (n 1).

17 Directive 2010/41/EU (n 1). 
logics through the creation of a European citizenship which extended the rights granted to workers to all citizens. ${ }^{18}$ Yet, the years 1999 and 2000 marked the real beginning of the fundamental rights era for the EU with the entry into force of the Amsterdam Treaty and the adoption of the European Charter of Fundamental Rights (hereinafter the Charter). Articles 21 and 23 guaranteeing equality as a fundamental right beyond the limited scope of employment bear witness to this evolution. In its summary of legislation on fundamental rights and non-discrimination, the EU legislator in fact states that ' $[\mathrm{b}] \mathrm{y}$ bringing fundamental rights to the fore, those who drafted the Treaty of Amsterdam were endeavouring to give formal recognition to human rights'. The Amsterdam Treaty therefore corresponds to a shift towards the constitutionalization of human rights as fundamental norms.

In 2009 the Lisbon Treaty entered into force and confirmed the existence of a fundamental right to non-discrimination by granting constitutional status to the Charter, to the same extent as Treaty provisions prohibiting non-discrimination such as Articles 2 and 3 TEU, and Articles 8 and 19 TFEU. Consequently, the prohibition of discrimination contained in its Article 21 and 23 became directly applicable within the scope of EU law. ${ }^{19}$ The following year the EU ratified the UN International Convention on the Rights of Persons with Disabilities (UNCRPD), an act which embodied the EU's enterprise to align the principle of equality of the Union's citizens with the international human rights regime. Moreover, promising discussions on the accession of the EU to the ECHR started at the same time, before reaching a stalemate in 2014 with Opinion $2 / 13 .{ }^{20}$ Despite the CJEU's opinion against the EU's accession to the ECHR, protection against discrimination in the EU has been gradually, if only partially, anchored into a European and international framework of fundamental and human rights. This is illustrated, inter alia, by the loose dialogue that the CJEU and the European Court of Human Rights (ECtHR) still maintain with each other. ${ }^{21}$ Finally, the human

18 One example is the freedom of movement, from which citizens could also benefit in addition to workers. This rights-based EU citizenship was subsequently confirmed in Zambrano at [41] and Dereci at [62] in 2011. See C-34/09 Gerardo Ruiz Zambrano v Office national de l'emploi (ONEm) EU:C:2011:124, [2011] ECR I01177 and C-256/11 Murat Dereci and Others v Bundesministerium für Inneres EU:C:2011:734, [2011] ECR 000 .

19 European Charter of Fundamental Rights of the European Union [2000] OJ C364/3 Article 21 on nondiscrimination states: ' 1 . Any discrimination based on any ground such as sex, race, colour, ethnic or social origin, genetic features, language, religion or belief, political or any other opinion, membership of a national minority, property, birth, disability, age or sexual orientation shall be prohibited. 2. Within the scope of application of the Treaty establishing the European Community and of the Treaty on European Union, and without prejudice to the special provisions of those Treaties, any discrimination on grounds of nationality shall be prohibited.' and Article 23 on equality between men and women states: 'Equality between men and women must be ensured in all areas, including employment, work and pay. The principle of equality shall not prevent the maintenance or adoption of measures providing for specific advantages in favour of the underrepresented sex'.

20 See Opinion 2/13 pursuant to Article 218(11) TFEU [2014] EU:C:2014:2454 and Recommendation SEC(2010) 305 final for a Council Decision authorising the Commission to negotiate the Accession Agreement of the European Union to the European Convention for the protection of Human Rights and Fundamental Freedoms (ECHR) [2010].

21 Judge Rosas has qualified this judicial dialogue as a 'semi-vertical relation', explaining that '[i]n actual practice, the Luxembourg judges follow very closely the case-law of the Strasbourg Court'. This is notably true in the field of fundamental rights, where '[s]ince the mid-1990s, the E.C.J. cite[s] the E.C.H.R. on a regular basis in their judgments' and 'the E.C.H.R., too, from time to time cites the case-law of the Luxembourg courts'. See A Rosas 'The European Court of Justice in Context: Forms and Patterns of Judicial Dialogue' (2008) 1 European Journal of Legal Studies 2, 126-8 and in particular at 127. See also D Spielmann, 'The Judicial Dialogue between the European Court of Justice and the European Court of Human Rights Or how to remain good neighbours after the Opinion 2/13' (2017) FRAME <http://www.fp7frame.eu/wp-content/uploads/2017/03/ECHRCJUEdialog.BRUSSELS.final_.pdf $>$ (accessed 16 August 
rights discourse promoted in the field of non-discrimination law is visible in the language chosen to justify the EU politics of equality today. To name just one example, the 2008 Proposal for a Horizontal Directive presents fundamental rights as one of the bigger aims of EU anti-discrimination law and policy. ${ }^{22}$

This linguistic dimension is not benign because, as Somek puts it, 'Member States find themselves forced to re-describe and to restructure their social world along the lines of the imagery of meaning generated in Commission and Council documents' ${ }^{23}$ The 'rights' discourse therefore proposes and diffuses a new cognitive scheme and conceptual categories though which to perceive non-discrimination law. It contributes to reshaping representations, norms and knowledge and, as the next sections show, has affected the way actors think, make, enforce and talk about nondiscrimination law.

\section{(iii) Enhancing the horizontal dimension of the principle of non-discrimination}

This three-pronged broadening, deepening and anchoring motion can be described, in the words of Muir, as 'transformative'. ${ }^{24}$ The transformative nature of equality ensues from the efforts of the legislator to increase the hold of the principle of non-discrimination over interpersonal relationships in various domains of social life. ${ }^{25}$ From a vertical principle protecting citizens against arbitrariness emanating from public authorities, it became, over time, a horizontal norm increasingly regulating large subsets of private social interactions among EU citizens' ${ }^{26}$ This change in fact translates into the reinforcement of the so-called privatization of the principle of equal treatment, which spreads horizontally into EU society. ${ }^{27}$ It has been argued that equality takes on a transformative function

2017), 18: after Opinion 2/13, '[b]oth courts follow closely each other's case law and are willing more or less to make the necessary adjustments in order to avoid blatant discrepancies as regards the level and modalities of protection of fundamental rights'. For a concrete example, see also C-83/14 CHEZ Razpredelenie Bulgaria AD v Komisia za zashtita ot diskriminatsia [2015] EU:C:2015:480 [46], [73] and C-188/15 Asma Bougnaoui and Association de défense des droits de l'homme (ADDH) v Micropole SA EU:C:2017:204 [28] and C-157/15 Samira Achbita and Centrum voor gelijkheid van kansen en voor racismebestrijding v G4S Secure Solutions NV EU:C:2017:203 [26].

22 See Commission (2008) (n 4). In its explanatory memorandum, the Commission states that '[the] proposal builds upon the strategy developed since the Amsterdam Treaty to combat discrimination and [...] will help to further the fundamental rights of citizens, in line with the EU Charter of Fundamental Rights'.

${ }^{23}$ Alexander Somek, Engineering Equality. An Essay on European Anti-Discrimination Law (Oxford: Oxford University Press 2011), 69.

24 For the EU's statement of intent on a right to non-discrimination 'in all areas of life', as quoted in the heading of this sub-section, see European Commission, 'Communication from the Commission to the European Parliament, the Council, the European Economic and Social Committee and the Committee of the Regions-Non-discrimination and equal opportunities: A renewed commitment' [2008] COM (2008) 0420 final. On the 'transformative function of EU equality law', see Muir (n 3). See also Mark Bell, 'The Principle of Equal Treatment: Widening and Deepening' in Paul Craig and Gráinne de Búrca (eds), The Evolution of EU Law (Oxford: Oxford University Press, 2011), 611-39.

25 See Muir (n 3).

${ }^{26}$ See ibid.

27 See Nobert Reich, 'The Impact of the Non-Discrimination Principle on Private Autonomy' in Dorota Leczykiewicz and Stephen Weatherhill (eds), The Involvement of EU Law in Private Law Relationships (Oxford: Hart Publishing, 2013). 
because it ultimately reshapes European societies through the direct injection of the nondiscrimination norm into micro-level interactions. ${ }^{28}$

Although the protection from gender- and nationality-based discrimination in the sphere of employment already regulated horizontal private relationships early on, the 2000 s equality laws extended horizontal regulation to more grounds within the broad realm of employment, and to the larger sphere of consumption of goods and services for gender and racial equality. ${ }^{29}$ This horizontal aspect becomes most visible when the principle of equal treatment encroaches upon private autonomy, notably freedom of contract. ${ }^{30}$ For instance, goods and services providers are forbidden to reject contractual partners because of their race or gender. ${ }^{31}$ Another obvious example is the obligation for a private employer to reasonably accommodate the disability of employees. The ensuing 'privatization' of the non-discrimination principle thus influences EU citizens' behaviours, choices attitudes, and habits. It contributes to a long-term strategy of eliminating harmful stereotypes and prejudices, which perpetuate inequality. In this sense, non-discrimination has been proclaimed both a fundamental human right and a socially transformative principle in the EU.

\section{B. The promotion of a general principle of non-discrimination by the european judiciary}

\section{(i) A historical engine in the field of non-discrimination law}

At the judicial level, the CJEU has historically been an active engine for the promotion of gender equality and non-discrimination based on nationality. It is the Court that breathed life into EU equality law. ${ }^{32}$ Efforts to transform European citizenship through equality in fact started with the direct horizontal effects recognized by the CJEU to Article 157 TFEU in the field of sex discrimination. ${ }^{33}$

28 See Muir (n 3), 1241 and 1253. Élise Muir links the horizontal dimension of the principle of nondiscrimination to a form of 'inter-personal equality'.

29 I use the adjectives 'broad' and 'expanded' to describe the spheres of 'employment' and 'consumption' as they cover an enlarged subset of areas such as social protection, professional training, healthcare, housing, etc. As already mentioned, the protection of race equality goes even further and includes education.

30 A good example of this is the recent national judgment Gareth Lee v Colin McArthur, Karen McArthur and Ashers Baking Company Limited [2016] NICA 39. The Ashers Bakery Court of Appeal decision found discrimination on the basis of sexual orientation in a private business transaction between customers and business owners, in application of the Northern Ireland Equality Act (Sexual Orientation) Regulations (NI) 2006. The protection afforded is broader than Directive 2000/78/EC, which only covers employment. Such a broad anti-discrimination protection in the field of goods and services was intended in the Horizontal Proposal that is still under discussion at the Council. The Court of Appeal decision was however subsequently reversed by the UK Supreme Court, see Lee (Respondent) v Ashers Baking Company Ltd and others (Appellants) (Northern Ireland) [2018] UKSC 49.

31 This, however, only applies to goods and services available to the public.

32 Muir (n 3), 1241.

33 Defrenne II [1976] (n 7) and Marshall [1986] (n 33) make clear that Treaty provisions-but not directives - can have direct horizontal effects in the field of sex discrimination. 
The Court pursued a similar strategy in the aftermath of the legislative reforms of the 2000s. As the legislative protection against discrimination extended, the Court gave birth to a general principle of non-discrimination that has taken EU non-discrimination law beyond its strict economic origins. ${ }^{34}$ 'From the narrow area of non-discrimination in the workplace', it has evolved towards 'a more embracing principle', enabling a high level of protection across a wide range of situations and for a large constituency of rights-bearers. ${ }^{35}$ When reviewing the case law of the Court in the field of non-discrimination, it appears that the EU judiciary has mainly resorted to two instruments to uphold equality in the EU legal order: the constitutional precedence of general principles of fundamental rights and the principle of effectiveness.

\section{(ii) Constitutionalizing the right to non-discrimination: carving out a general principle in the name of fundamental human rights}

In retrospect, the Court's post-2000 anti-discrimination jurisprudence upheld a double function for the principle of equality in the EU legal order. The CJEU progressively carved out a general principle of non-discrimination to which it granted de facto constitutional status even before the Charter acquired the status of primary law. ${ }^{36}$ Constitutionalizing the principle of equality strategically overlapped with, and complemented, the gradual shift of the equality discourse towards the language of fundamental rights. Equality hence embodied two functions that seemed to naturally complement each other, as both a general principle of EU law and a fundamental right. This rhetorical evolution at the judicial level furthered the Commission's efforts to entrench equality, and European citizenship at large, in the realm of fundamental rights.

At the outset, the CJEU adopted an activist stance on the question of what Muir calls the 'transformative function' of the principle of non-discrimination. ${ }^{37}$ In the much-commented and controversial Mangold decision in 2005, the Court recognized a general principle of nondiscrimination in respect of age ${ }^{38}$ Remarkably, it granted direct effects to the said principle in a horizontal dispute between EU citizens, even though the transposition delay of Directive 2000/78/EC had not expired. This reversed the Court's usual non-discrimination reasoning as the CJEU considered the "various international instruments and the constitutional traditions common to the Member States' ${ }^{39}$ emphasized in the directive's recital as the source of a general principle of nondiscrimination of constitutional standing, instead of deducing the prohibition of discrimination from the relevant directive. While the principle gave expression to the (yet to be transposed) directive, it sufficed alone to produce effects.

34 Sacha Prechal, 'Achievements and Trends in EU Gender Equality Law' (2005)

$<$ http://www.euroinfo.ee/malta/pdf/c4.pdf> (accessed 10 May 2016), 33.

35 Ibid.

${ }^{36}$ Mangold [2005] (n 36) was decided in 2005 while the Charter acquired constitutional status in 2009. See Muir (n 3), 1244 and Reich (n 27), 256-60.

${ }^{37}$ Muir (n 3).

38 Mangold (n 64).

39 Ibid at [74]. 
This stance was repeated in 2010 in Kücükdeveci, ${ }^{40}$ another case of age discrimination, where the Court confirmed the existence of the general principle. Faced with a lack of direct applicability of the directive in horizontal disputes, the CJEU maintained the horizontal direct effects of the general principle of non-discrimination. This approach was subsequently confirmed in Dansk Industri in 2016. ${ }^{41}$ The Court first clarified that the general principle was horizontally and directly effective where the directive could not apply (ie in a horizontal dispute). Second, it explained that the general principle of non-discrimination, as an expression of the 'fundamental principle of equal treatment', prevailed over other general principles of EU law such as legal certainty. ${ }^{42}$ The reasoning in the above-mentioned line of landmark cases therefore sanctioned the constitutional status of the general principle of non-discrimination in EU law, as well as its privileged position in the hierarchy of norms because of its nature as a fundamental right. ${ }^{43}$ As a consequence, the general principle of non-discrimination has displayed far-reaching transformative effects at the level of social interactions between EU citizens.

One limitation to this jurisprudence is, however, that granting horizontal direct effects to the general principle of non-discrimination has so far only been used as an instrument to secure the uniform application of EU equality law. Concretely, these effects apply insofar as national legislation conflicts with EU law and needs to be dis-applied in a horizontal dispute, where directives do not enjoy direct effect. ${ }^{44}$ Hence, they can be described as 'subsidiary' horizontal direct effects: the general principle applies directly so long as the directive itself does not. ${ }^{45}$ This mechanism stretches the uniform application of EU non-discrimination law to private disputes, striking down illegal

40 C-555/07 Seda Kücükdeveci v Swedex GMBH \& Co. KG EU:C:2010:21, [2010] ECR I-00365.

41 C-441/14 Dansk Industri (DI) v Succession Karsten Eigil Rasmussen [2016] EU:C:2016:278.

See also C-414/16 Vera Egenberger v Evangelisches Werk für Diakonie und Entwicklung eV [2018] EU:C:2018:257 where the general principle of non-discrimination was discussed by the CJEU in relation to religion. This case was however decided after the finalization of this article and therefore cannot be discussed in detail here.

42 Dansk Industri [2016], [26] (n 41).

43 This might be due to its 'structural and fundamental nature' as both an expression of EU national constitutional traditions and a keystone in the history of EU integration. See Sune Klinge, 'Dialogue or disobedience between the European Court of Justice and the Danish Constitutional Court? The Danish Supreme Court challenges the Mangold-principle' (EU Law Analysis, 13 December 2016).

The importance and scope given to the general principle of non-discrimination therefore denotes the prominence given to individual equality rights over other legal concerns. See Urška Šadl and Sabine Mair 'Mutual Disempowerment: Case C-441/14 Dansk Industri, acting on behalf of Ajos A/S v Estate of Karsten Eigil Rasmussen and Case no. 15/2014 Dansk Industri (DI) acting for Ajos A/S v The estate left by A' (2017) 13(2) European Consitutional Law Review, 347.

44 It is not certain, indeed, that the Court would have upheld the horizontal direct effect of the general principle in the absence of a national law explicitly conflicting with a directive.

45 Giovanni Zaccaroni, 'More on the horizontal direct effect of the principle of nondiscrimination on the ground of age: Dansk Industries (DI)' (EU Law Analysis, 14 July 2016)

$<$ http://eulawanalysis.blogspot.com/2016/07/more-on-horizontal-direct-effect-of.html> (accessed 10 October 2016). 
provisions but also securing individual rights for EU citizens ${ }^{46}$ However, after Dansk Industri (2016) and in view of the Danish Constitutional Court's reaction, the boundaries between the exclusionary effects of the general principle of non-discrimination (ie the disapplication of state legislation) and the potential substitutionary effects linked to the de facto application of the nondiscrimination directive in a legal relationship between private parties (ie the alteration of private law-making) remain blurry. ${ }^{47}$ The scope of these horizontal direct effects being ambiguous, the frontiers of the transformative reach of equality as a constitutional fundamental right remain imprecise. $^{48}$

In parallel, the Court's constitutionalization of the right to non-discrimination took on other forms. From a discursive perspective, it is interesting to note that the plurality of terminology of the beginnings was progressively substituted by a uniform language. From Mangold onwards, the terms used by the Court shifted from a 'principle of equality' to 'a principle of equal treatment' and then to a 'principle of non-discrimination'. ${ }^{49}$ Although their content largely overlaps, it is the latter that is now clearly identified as a general principle of EU law. Furthermore, at the level of the CJEU too, the constitutional bedrock of the principle of non-discrimination became increasingly associated with the framework of fundamental and human rights. As early as 2006, the Court anchored equality in the subset of fundamental rights that 'form an integral part of the general principles of Community Law'. ${ }^{50}$

46 Dansk Industri [2016], [36] (n 41). See also Zaccaroni (n 45). For a detailed analysis, see Koen Lenaerts, 'The principle of equal treatment and the European Court of Justice' (2013) 23 Il Diritto dell'Unione Europea 461.

There is a debate about whether the use of a general principle to disapply conflicting national law belongs to the principle of primacy of EU law or to the principle of direct effect ('primacy model'), or if the principle of primacy is only a consequence of the principle of direct effect ('trigger model'). See Koen Lenaerts and José Gutiérrez-Fons, 'The Constitutional Allocation of Powers and General Principles of EU Law' (2010) 47 CML Rev, 1629, 1640-1 and Michael Dougan, 'When worlds collide! Competing visions of the relationship between direct effect and supremacy’ (2007) 44(4) CML Rev, 931.

47 As Lenaerts and Gutiérrez-Fons explain, the distinction between exclusionary and substitutionary effects ensuing from the application of a general principle (that has the value of primary law) is not clear and often becomes blurry, as the case of Dansk Industri [2016] (n 41) exemplifies. See Lenaerts and Gutiérrez-Fons (n 46). See Mirjam de Mol, 'Dominguez: A Deafening Silence. Court of Justice of the European Union (Grand Chamber) Judgment of 24 January 2012, Case C-282/10, Maribel Dominguez v. Centre informatique du Centre Ouest Atlantique and Préfet de la région Centre' (2012) 8 European Constitutional Law Review, 280, 281 and Elena Gualco and Luísa Lourenço, "Clash of Titans". General Principles of EU Law: Balancing and Horizontal Direct Effect' (2016) 1 European Papers, 643.

48 It is disputed in the doctrinal debate whether horizontal direct effects only strike down national provisions or also create new rights per se. See (n 45) to (n 47).

49 This finding relies on a systematic case law search conducted on the Curia database and refined through a qualitative analysis software. See Raphaële Xenidis, 'Shaking the Normative Foundations of EU Equality Law: Evolution and Hierarchy Between Market Integration and Human Rights Rationales', EUI Working Paper (2017) available at $<$ http://cadmus.eui.eu/bitstream/handle/1814/45489/LAW_2017_04.pdf? sequence=3>.

50 C-13/05, Sonia Chacón Navas v Eurest Colectividades SA. [2006] EU:C:2006:456, [56]. However, contrary to Mangold [2005] (n 35), the Court does not use the fundamental rights basis to recognize protection: 'it does not follow from this that the scope of Directive 2000/78 should be extended by analogy beyond the discrimination based on the grounds listed exhaustively in Article 1 thereof.' 
The emphasis put in judicial language on the nature of equality as a fundamental right has been particularly strong from 2009 onwards, as the general principle of non-discrimination in its multiple forms has been increasingly invoked in association with the Charter. For instance, a search of the case law related to Directives 2000/78/EC and 2000/43/EC reveals that from 2010 to 2017, nineteen cases deployed the general principle of non-discrimination together with Article 21 of the Charter, which prohibits discrimination..$^{51}$ The first of them, Kücükdeveci (2010), recalls that the 'principle of non-discrimination on grounds of age [...] must be regarded as a general principle of European Union law' and that 'the Charter [...] is to have the same legal value as the Treaties', notably Article 21. ${ }^{52}$ In FOA (2014), the CJEU recognized that 'the fundamental rights which form an integral part of the general principles of EU law include the general principle of nondiscrimination'. ${ }^{53}$ This shift was also confirmed in the widely-discussed Test-Achats (2011) case, in which the Court used Article 21 and 23 of the Charter as the main normative sources to strike down a provision of EU law deemed discriminatory. ${ }^{54}$ It declared invalid a legislative exemption contained in Article 5(2) of Directive 2004/113/EC allowing gender-differentiated insurance premiums and benefits precisely because it derogated from the fundamental right to, and principle of, equal treatment. Finally, in Glatzel (2014), Chatzi v Ypourgos Oikonomikon (2016), and Fries (2017), the Court also confirmed that Article 20 of the Charter, dealing with equality before the law, was an expression of the fundamental nature of the general principle of equal treatment. ${ }^{55}$

Hence the constitutional status of the right to non-discrimination, already enshrined in Article 19 TFEU, has progressively been furthered not only because of its recognition as a general principle, but also because of its anchoring in the Charter. The framing of the principle of non-

51 This finding is based on a systematic case law search, see (n 40). These cases are Kücükdeveci [2010], [22] (n 40); Joined cases C-297-10 and C-298/10 Sabine Hennigs (C-297/10) v Eisenbahn-Bundesamt and Land Berlin (C-298/10) v Alexander Mai EU:C:2011:560 [46]-[47]; C-447/09 Reinhard Prigge and Others v Deutsche Lufthansa AG EU:C:2011:573, [2011] ECR I-08003, [38]; C-391/09 Malgožata Runevič-Vardyn and Łukasz Pawet Wardyn v Vilniaus miesto savivaldybes administracija and Others [2011) EU:C:2011:291 [43]; C-546/11 Dansk Jurist- og Økonomforbund v Indenrigs- og Sundhedsministeriet [2013] EU:C:2013:603 [40], C-476/11 HK Danmark acting on behalf of Glennie Kristensen v Experian A/S [2013] EU:C:2013:590 [19], [31], [32], [37], [45], [69]; C-530/13 Leopold Schmitzer v Bundesministerin für Inneres [2014] EU:C:2014:2359 [22]; C-201/13 Johan Deckmyn and Vrijheidsfonds VZW v Helena Vandersteen and Others [2014] EU:C:2014:2132 [30]; C-356/12 Wolfgang Glatzel v Freistaat Bayern [2014] EU:C:2014:350 [40]; C416/13 Mario Vital Pérez v Ayuntamiento de Oviedo [2014] EU:C:2014:2371[25]; C-432/14 Ov Bio Philippe Auguste SARL [2015] EU:C:2015:643, [21], [40]; C-529/13 Georg Felber v Bundesministerin für Unterricht, Kunst und Kultur [2015] EU:C:2015:20 [15]; CHEZ [2015] [28], [42], [58], [72] (n 21); C-539/15 Daniel Bowman v Pensionsversicherungsanstalt [2016] EU:C:2016:977 [19]; Dansk Industri [2016], [22] (n 41); C122/15 Proceedings brought by C [2016] EU:C:2016:391 [18]; C-406/15 Petya Milkova v Izpalnitelen direktor na Agentsiata za privatizatsia i sledprivatizatsionen kontrol [2017] EU:C:2017:198, [55], [64]; C143/16 Abercrombie \& Fitch Italia Srl v Antonino Bordonaro [2017] EU:C:2017:566 [17]; C-190/16 Werner Fries v Lufthansa CityLine GmbH [2017] EU:C:2017:513 [28].

52 Kücükdeveci [2010], [21]-[22] (n 40).

53 C-354/13 Fag og Arbejde (FOA) acting on behalf of Karsten Kaltoft v Kommunernes Landsforening (KL) acting on behalf of the Municipality of Billund EU:C:2014:2463 [2014], [32]. In this case no link was established between the general principle of non-discrimination and the Charter because the matter concerned was deemed to lie outside scope of EU law and the Charter not to apply.

54 C-236/09 Association Belge des Consommateurs Test-Achats ASBL and Others v Conseil des ministres [2011] ECLI:EU:C:2011:100 [30].

55 Glatzel [2014], [43] (n 51); C-149/10 Zoi Chatzi v Ypourgos Oikonomikon [2016] ECLI:EU:C:2010:534, [63] and Fries [2017] [29] (n 48). 
discrimination as a fundamental human right therefore provides a double constitutional anchor, which reinforces the transformative ambit of equality in the EU.

\section{(iii) Guaranteeing the effectiveness of the right not to be discriminated against}

The Court's jurisprudence was a game-changer insofar as it provided a bold and extensive interpretation of the directives so as to ensure effectiveness. ${ }^{56}$ Several jurisprudential innovations, along with the Mangold line of case law, show how the principle of effectiveness was used to advance non-discrimination both as a right and a core principle of social life. Interestingly, this is particularly true where non-discrimination served to ensure people's participation in the labour and consumption market.

First, as the previous section has already made clear, the horizontal direct effects of the general principle of non-discrimination recognized in Mangold largely contributed to the advancement of the rights contained in the new directive. ${ }^{57}$ Further, the Court has also taken into account the spirit of the law, either by giving weight to secondary objectives expressed in the recitals of the directives, Council recommendations, and policy frameworks, in particular when related to employment, or by using international standards to back the effective interpretation of nondiscrimination rights.

One of the most eloquent examples is CHEZ (2015), where the Court invoked the Convention together with case law from the ECtHR, as well as the International Convention on the Elimination of all Forms of Racial Discrimination in order to interpret Directive 2000/43/EC. ${ }^{58}$ The CJEU has made an even more important use of the UNCRPD, to which the EU has been a party since 2009. For instance, in recent case law the CJEU has tended, in light of the UNCRPD, to endorse a social model of disability as put forward in international law in order to guarantee the effective participation of workers living with disabilities in the labour market. ${ }^{59}$ In Odar (2012) and in the joined cases Ring and $H K$ (2013), the Court's reasoning fostered 'the effectiveness of ... [measures that] ... take account of the specific difficulties and risks faced by severely disabled workers' and the 'full and effective participation of persons with disabilities in professional life on an equal basis with other workers' ${ }^{60}$ In FOA (2014), the principle of effectiveness determined the

56 Muir (n 3), 1249-52 and in particular at 1244.

57 See Mangold [2005] at [78] (n 35): 'It is the responsibility of the national court to guarantee the full effectiveness of the general principle of non-discrimination in respect of age, setting aside any provision of national law which may conflict with Community law, even where the period prescribed for transposition of that directive has not yet expired.' Similarly, see Kücükdeveci [2010] at [51] and [53] (n 40) and Dansk Industri [2016] at [35] (n 41).

58 CHEZ [2015], [46], [73] (n 21).

59 Authors describe a shift between a medical model as put forward for instance in 2006 in Chacón Navas [2006] (n 50) and a more social model in the years following the ratification of the UNCRPD. See e.g. Anna Lawson and Lisa Waddington 'The unfinished story of EU disability non-discrimination law' in Alan Bogg, Cathryn Costello, and A. C. L. Davies (eds), Research Handbook on EU Labour Law (Cheltenham: Edward Elgar Publishing, 2016), 482-3.

60 C-152/11, Johann Odar v Baxter Deutschland GmbH [2012] EU:C:2012:772, [67] (emphasis added).

Joined cases C-335/11 and C-337/11 HK Danmark, acting on behalf of Jette Ring $v$ Dansk almennyttigt Boligselskab and HK Danmark, acting on behalf of Lone Skouboe Werge v Dansk Arbejdsgiverforening acting on behalf of Pro Display A/S [2013] EU:C:2013:222, [54] (emphasis added). 
Court's understanding of obesity as a disability when it hinders a worker's participation in the labour market. ${ }^{61}$ Finally, in Milkova (2017), the principle of effectiveness also served to reassert that 'Article 7(2) of Directive 2000/78 is to authorise specific measures aimed at effectively eliminating or reducing actual instances of inequality affecting people with disabilities'. ${ }^{62}$

The principle of effectiveness has also served to adapt the procedural rules of nondiscrimination jurisprudence to ensure the continuity of equality as a social value. For instance in Feryn (2008), the Court took a major step in establishing a presumption of direct racial discrimination even in the absence of identified victims. ${ }^{63}$ It considered that public racist statements emanating from a major Belgian company deterred potential racial minority workers from applying for open positions and thus shifted the burden of proof onto the defendant. ${ }^{64}$ The same principle applied in ACCEPT (2013), where the patron of a Romanian football team had publicly made homophobic statements in the media. ${ }^{65}$ The CJEU considered that there was no need for victims to be identified to establish a presumption of discrimination and concluded that the national court may shift the burden of proof onto the defendant. ${ }^{66}$ These two cases also show another application of the principle of effectiveness. In ACCEPT (2013) the Court decided that symbolic sanctions against the football club would be inappropriate and underlined, in both cases, that sanctions should instead be 'effective, proportional and dissuasive' to be compatible with EU non-discrimination law. ${ }^{67}$

In addition, the principle of effectiveness has been used to interpret the rules of evidence in a manner that would ensure the validity of the principle of non-discrimination. In Meister $^{68}$ (2012), the Court relied on the principle of effectiveness to find that an employer's refusal to disclose information pertaining to a recruitment process could count towards the establishment of

The EU became a party in the UNCRPD in 2010 but the 'EU Framework for the UN Convention on the Rights of Persons with Disabilities' was only adopted in 2013.

61 FOA [2014], [64] (n 53). Obesity constitutes a disability where it prevents the worker's effective participation in professional life on an equal basis with other workers.

62 Milkova [2017], [47] (n 51) (emphasis added).

63 C-54/07 Centrum voor gelijkheid van kansen en voor racismebestrijding v Firma Feryn NV EU:C:2008:397 [2008] ECR I-05187.

64 The litigant in this case was the Belgian equality body, the Centre for Equal Opportunities and Fight against Racism, which transformed in 2012 into the Interfederal Center for Equal Opportunities. See Feryn [2008] at [40] (n 64).

65 C-81/12 Asociaţia ACCEPT v Consiliul Naţional pentru Combaterea Discriminării [2013]

EU:C:2013:275.

66 Ibid, [36]-[37], [55].

67 Ibid, [61]-[64], [69] and Feryn [2008] at [40] (n 64) stating that the 'rules on sanctions [...] must be effective, proportionate and dissuasive' (emphasis added).

68 C-415/10 Galina Meister v Speech Design Carrier Systems GmbH [2012] EU:C:2012:217, [39]: 'It is not, however, inconceivable that a refusal of disclosure by the defendant, in the context of establishing such facts, is liable to compromise the achievements of the objective pursued by that directive and, in particular to deprive that provision of its effectiveness' (emphasis added). However, the principle of effectiveness is overridden by other concerns. 
a presumption of discrimination. ${ }^{69}$ In fact, in this case of alleged employment discrimination on the multiple bases of age, gender, and ethnic origin, the absence of such evidence would otherwise undermine the effectiveness of non-discrimination law, notably because ' $[\mathrm{d}]$ iscrimination has the reputation of being particularly hard to substantiate'. ${ }^{70}$

Finally, the principle of effectiveness has also intervened to secure effective definitions of protected groups. Notably, in Coleman (2008) and CHEZ (2015), the Court pushed for effectiveness through recognizing that so-called 'discrimination by association' amounted to unlawful discrimination. ${ }^{71}$ In Coleman (2008), it found that discriminating against a worker because she needs accommodation of her working conditions to be able to take care of her disabled son constitutes 'discrimination by association' on grounds of disability. ${ }^{72}$ In $C H E Z$ (2015), the CJEU identified racist discrimination 'by association' against a member of the Bulgarian ethnic majority. This apparent contradiction arose because the victim was harmed by a discriminatory policy targeting an entire neighbourhood based on racist stereotyping against a Roma minority. The CJEU offered an in-depth contextual analysis of the role of racist prejudices in the perpetuation of discrimination and inequality and rebutted dangerous essentialist interpretations of the concept of ethnicity, thereby securing an effective interpretation of Directive 2000/43/EC.

These examples show how the principle of effectiveness has recently ensured a more far-reaching interpretation of the prohibition to discriminate, at least where it affected the participation of EU citizens in the labour and consumption market. In some instances, the Court did not shy away from punctually interfering, sometimes bluntly, with member states' autonomy to enforce the full range of rights deriving from the Charter and the general principle of nondiscrimination and to ensure that exceptions are only strict and narrow. ${ }^{73}$ Through its decisions and language, the Court has at times displayed a certain willingness to propel equality towards both a fundamental human right and a core social norm structuring public and private relationships in the

69 Meister [2012], [38]-[39] (n 68).

70 Ibid, Opinion of AG Mengozzi, [1].

71 CHEZ [2015], [56] (n 21); C-303/06 Coleman v Attridge Law and Steve Law EU:C:2008:415 [2008] ECR I-05603, [38], [50].

72 See Coleman [2008], [48], [51] (n 71): '... the effectiveness of Directive 2000/78, would be undermined if an employee in the claimant's situation cannot rely on the prohibition of direct discrimination ... where it has been established that he has been treated less favourably than another employee ... on the grounds of his child's disability, and this is the case even though that employee is not himself disabled' and '[w] here it is established that an employee ... suffers direct discrimination on grounds of disability, an interpretation of Directive 2000/78 limiting its application only to people who are themselves disabled is liable to deprive that directive of an important element of its effectiveness and to reduce the protection which it is intended to guarantee' (emphasis added).

73 Age discrimination cases, notably, have been a good opportunity for the Court to put non-discrimination rights into effect, thus deepening the integration of labour markets. See the age discrimination case law series, e.g. C-341/08 Domnica Petersen v Berufungsausschuss für Zahnärzte für den Bezirk Westfalen-Lippe EU:C:2010:4, [2010] ECR I-00047; Prigge [2011] (n 51); C-476/11 H.K. Danmark acting on behalf of Glennie Kristensen v Experian A/S EU:C:2013:590, [2013]. 
EU. ${ }^{74}$ At the same time, these efforts have not been uniform. ${ }^{75}$ This inconstancy can be understood as the reflection of a fundamental tension at the heart of the principle of non-discrimination.

\section{What substance for non-discrimination law between market- oriented and human rights-driven concerns?}

As demonstrated above, efforts have been made both at the political and at the judicial level to requalify the principle of non-discrimination as a fundamental human right. This section takes Westen's proposition that equality is 'a "form" for stating moral and legal propositions whose substance originates elsewhere' and 'a "form" of discourse with no substantive content of its own' seriously. ${ }^{76}$ The next paragraphs demonstrate how, through shifting the framing of equality, the EU anchored its reformative enterprise within a broader disruptive narrative. Through opposing the Union's 'new' human rights mandate to its more traditional mission of promoting economic integration, this narrative fulfils both a legitimizing and a modernizing function. ${ }^{77}$ However, the dichotomy constructed between these two overarching normative frames is artificial and, in fact, the EU non-discrimination system cannot be understood through this binary opposition. Rather, it constitutes a hybrid locus, which seems characterized by its fluctuating substance.

\section{A. Transforming non-discrimination law? A disruptive narrative}

\section{(i) The right to non-discrimination: a cornerstone of the EU human rights agenda}

The story of the principle of non-discrimination is clearly rooted in an instrumental conception of equal treatment as a means of economic integration. It is well known in fact that EU nondiscrimination law is not born out of a genuine effort to protect the fundamental human right to equality. Rather, its roots lie in the willingness to eliminate distortions of competition to realize a single market. In order to integrate national markets and to ensure freedom of circulation for workers, a prohibition to discriminate based on nationality and sex was inserted in the Treaty. ${ }^{78}$ Hence, non-discrimination rights primarily served the indirect purpose of securing economic participation and growth. ${ }^{79}$

74 The only protected ground for which the principle of effectiveness had not, up to January 2017, played a role was religion.

${ }^{75}$ Cases such as Achbita [2017] (n 21) or C-443/15 David L. Parris v Trinity College Dublin and Others EU:C:2016:897 are examples of instances where the Court could have gone much further in securing the proper enforcement of non-discrimination rights.

76 Westen (n 6), 577-8.

77 See e.g. Erving Goffman, Frame analysis: An essay on the organization of experience (Boston, MA: Harvard University Press, 1974).

78 During the negotiations of the Rome Treaty, France argued that a principle of equal pay for women and men was necessary to avoid market and competition distortions among member states. It is, however, only well after the adoption of the relevant Treaty provision in 1957, in fact during the 1970s, that the CJEU has been active in promoting gender equality. Similarly, the prohibition to discriminate based on nationality was introduced to protect the free movement of workers.

79 France is, for instance, responsible for pushing for equal pay between men and women. 
Yet, as the first section of this article showed, the reforms of the 2000s reflect an alternative rationale. Translated into the language of human rights, non-discrimination law became increasingly embedded in the broader framework of equality and promoted as one of the fundamental values of the EU. In the words of CJEU Judge Prechal herself, 'the rationales underlying equality and non-discrimination' shifted 'away from the economic integration motives towards the recognition of equality and non-discrimination as a self-standing fundamental right' ${ }^{80}$ Other commentators spoke, as early as 2002, of a new guiding rationale in EU non-discrimination law, with concepts like 'fairness, autonomy, human dignity and respect for human rights' as well as 'the creation of a better society' as leitmotivs. ${ }^{81}$ This framing exercise did not only take place at the legislative and jurisprudential levels as exposed above, but also translated in a new political narrative.

After the human rights project had been put aside for decades in order to privilege economic integration, constructing non-discrimination law as a pillar of the EU's protection of fundamental rights was part of an overarching discursive strategy aimed at giving a new impetus to the Union's mandate in a moment of stagnation. ${ }^{82}$ As integration was running out of steam at the beginning of the 2000s after important achievements in the single market, the human rights narrative permitted the Union to regain legitimacy. It seems that the EU found in 'the language surrounding human rights $[\ldots]$ a powerful language with which to express political claims'. ${ }^{83}$ By downplaying the market integration rationale and using the great purchasing power of the human rights discourse, EU decision makers could at the same time respond to internal challenges, keep up with international standards, and restore the Union's image. The new emphasis on the EU as a promoter of rights manifested itself in two concrete ways. Externally, the EU's role in international security and peace building missions increased. ${ }^{84}$ Internally, strengthening and reframing the historical protection against discrimination was an ideal project to respond to the inner and outer legitimacy challenges faced by the EU at the time.

Since the 1980s racist and xenophobic movements had in fact become more and more vociferous in the EU. The long-term work of coalitions of European NGOs fighting against racism and social exclusion, among which were the Starting Line Group and the Social Platform, raised broad awareness about this problematic context. These initiatives led to a Treaty reform

80 Sacha Prechal, "'Discrimination does not fall down from heaven": the context and evolution of nondiscrimination in EU law' (Eric Stein Working Paper, 2009), 8, 13.

81 Evelyn Ellis, 'The principle of non-discrimination in the Post-Nice Era', in Arnull and Wincott (eds.), Accountability and Legitimacy in the European Union (Oxford: Oxford University Press, 2002), 293.

82 A finer look at the EU's integration history reveals that the human rights rationale has always been a longterm goal of the Union but was left aside in favour of economic integration for the purpose of finding a compromise on the modes of integration at the beginning of the European construction. The human rights rationale has recently re-appeared as a guiding and legitimizing principle, first for the Union's external action, and subsequently for its internal action in a time of existential, economic, and values crisis. See Gráinne De Búrca, 'The Road Not Taken: The EU as a Global Human Rights Actor' (2011) 105 The American Journal of International Law, 649.

83 Marie-Bénédicte Dembour, 'What are Human Rights: Four Schools of Thought' in Thomas Cushman (ed.), Handbook of Human Rights (New York: Routledge, 2012).

84 Beyond the constitutional changes operated with the Charter and the Lisbon Treaty, further reforms including the creation of a Fundamental Rights Agency replacing the Vienna monitoring centre against racism and xenophobia, and the creation of a network of experts on fundamental rights testify to this new rationale. See ibid, 671. 
constitutionalizing the fundamental right not to be discriminated against in the form of Article 13 TEC in 1997, and later to the adoption of Directive 2000/43/EC and Directive 2000/78/EC in 2000. ${ }^{85}$ The Race Equality Directive and the Employment Equality Framework Directive were approved quickly in light of the political background. ${ }^{86}$ Triggering this political mobilization was the entry of the populist and far-right party FPÖ led by controversial politician Jörg Haider in the Austrian governmental coalition in 2000, after it had gained a high level of votes at the 1999 general elections. Fearing violations of human rights, the centre-left majority sitting at the EU Council of Ministers at the time of the discussions embarked upon a series of legal reforms and political measures to introduce safeguards for fundamental rights, despite the original resistance of Member States. ${ }^{87}$ The Union's affirmation of its human rights mandate thus constituted the European governments' emergency response to the threats posed by the rise of right-wing extremism. ${ }^{88}$ In the context of this legitimacy crisis, the fight against discrimination represented a symbolic opportunity for the EU to show unity and to push forward a form of de minimis European citizenship, in which the human rights frame dealt as the lowest common value denominator.

Pressure to increase attention to human rights at the EU level also came from international fora, where initiatives to improve the protection of vulnerable groups multiplied in the 2000s. Global or regional concerns like the ageing of the population and thus the need to protect older workers, growing international attention to the rights of people living with disabilities, and international discussions around multiple inequalities also explain the readiness of EU institutions to reform non-discrimination law. ${ }^{89}$ For instance, at the dawn of the 2000 s negotiations over the yet-tobecome CRPD were called for by international NGOs in the UN. The committees enforcing already existing conventions such as the Convention on the Elimination of Racial Discrimination (CERD), the Convention on the Elimination of All Forms of Discrimination Against Women (CEDAW), and the International Covenant on Civil and Political Rights (CCPR) also actively issued new general

85 This initiative behind Directive 2000/43/EC found huge support in the EU at the time, with 400 governmental and non-governmental organizations standing behind the proposal, as well as the European Parliament. The 1992 draft was revised in 1998, taking into account the 1997 Treaty reform. See Jan Niessen and Isabelle Chopin (eds), The Development of Legal Instruments to Combat Racism in a Diverse Europe (Leiden: Martinus Nijhoff Publishing, 2004), 95-110.

Directive 2000/78/EC was notably rendered possible by the cooperation work of The Social Platform, Solidar, the Youth Forum, the European Federation for Intercultural Learning, the European Human Rights Foundation, and diverse religious organizations with the Commission. See Carlo Ruzza, 'Human rights, antiracism, and EU advocacy coalitions' in Lydia Morris (ed.), Rights: Sociological Perspectives (Abingdon: Routledge, 2006).

86 The fact that the adoption of the Race Equality Directive was unusually consensual accounts for its exceptional character. In fact, in the political context of the 2000s the feeling of emergency about the human rights situation probably explains the absence of challenge based on a lack of EU competence.

87 See ibid, 105.

88 See Ruzza (n 85).

89 These debates took on importance at the beginning of the 2000s, as the discussions around the CRPD at the end of the 19990s, around employment rates at the Lisbon Council 2000, and around multiple forms of inequality at the 56th session of the UN General Assembly in 2000 took place. See Presidency Conclusions, Lisbon European Council (23 and 24 March 2000) available at $<$ http://www.europarl.europa.eu/summits/lis1_en.htm> (accessed 22 August 2017) and UNGA 'Report of the Committee on the Elimination of Racial Discrimination' UNGAOR 55th Session Supp No 18 UN Doc $\mathrm{A} / 55 / 18(2000)$. 
recommendations to strengthen the international protection of minorities against discrimination..$^{90} \mathrm{~A}$ final example is the adoption of the Charter in 2000, which matches the ECHR in the field of nondiscrimination provisions and thus further anchored the principle of non-discrimination within both a European and an international human rights framework. Hence, in less than two decades, the EU both consolidated and reframed its non-discrimination system, responding to both internal and external pressure. On the one hand, EU institutions, seeking legitimacy and a revival of integration, could exploit a window of opportunity created both by the political climate and by the activism of the EU civil society. On the other hand, the Union found in non-discrimination law an adequate response to the globalization of international human rights discourses. ${ }^{91}$ These examples show how equality has been used as a 'form' or a vehicle for the Union's evolving normative and political agenda. ${ }^{92}$

\section{(ii) Normative tensions in the substance of the principle of equality}

The fundamental rights frame, despite its relative newness, has established itself as one of the main normative foundations of the European equality law project today. It challenged the narrower historical framing of non-discrimination law as a catalyst for market integration and a mere de facto safeguard for workers' social rights. Non-discrimination thereby became a right - the legal basis for individuals to claim equal treatment in public and private interactions - and a core dimension of EU citizenship, that is, a strong legitimizing narrative. This evolution, presented as a transformation of the normative foundations of EU equality law, carries with it a rhetoric of disruption, which rests on a series of discursive dichotomies. This section exposes some of the normative frictions and clashes that these binary oppositions seem to create.

While the principle of non-discrimination was historically instrumental to the Union's primarily economic mandate, the right to non-discrimination is presented as genuine, imperative, and fundamental in what Somek calls the 'newspeak' of the EU institutions. ${ }^{93}$ Market harmonization seems to have been substituted at the centre of European integration by concerns over human diversity and differences, at least at the symbolic level ${ }^{94}$ Given the mandate conferred on the EU, non-discrimination rights as guaranteed by EU law mainly span over the labour and consumption markets, which contrasts with the traditionally assumed universality of human rights. If nondiscrimination indeed became a right that human beings possess qua humans, then we should observe an imperative principle with per se validity, or even a 'trump' to be given priority over other

90 For instance the CERD issued a General recommendation No. 27 on discrimination against Roma, a General Recommendation No. 26 on compensation for victims of racial discrimination, and a General recommendation No. 25 on gender-related dimensions of racial discrimination in 2000, the CEDAW adopted a General recommendation No. 24 on discrimination against women in health-related matters in 1999, while the Human Rights Committee adopted a General Comment No. 28 in 2000 on the equality of rights between men and women.

91 De Búrca (2011) (n 82), 651.

${ }^{92}$ Westen (n 6).

${ }^{93}$ Somek (n 23), 11.

94 Duncan Kennedy, 'Three Globalizations of Law and Legal Thought: 1850-2000' in David M Trubek and Alvaro Santos (eds), The New Law and Economic Development: A Critical Appraisal (Cambridge: Cambridge University Press 2006), 65. 
politico-social objectives. ${ }^{95}$ This definition contrasts with the utilitarian understanding, promoted at the start of the EU integration process, of non-discrimination rights as functional vehicles enforcing a distinct set of (liberal) socio-political preferences. In addition, setting social protection safeguards in the form of non-discrimination rights necessarily restricts the private autonomy of market actors, which is a funding element of liberal capitalist societies. Hence, the fundamental right to equality collides with concerns of economic efficiency, party autonomy, freedom of contract and the right to differentiate. However, non-discrimination law's horizontality, that is its capacity to shape private interactions and thus to constitute a structuring norm in social relations, simultaneously goes beyond the traditional grounding of human rights in public law and vertical relationships. ${ }^{96}$ Nondiscrimination law thus is at the centre of competing normative frames, each of which bears its own symbolic, discursive, and ideological allegiances. ${ }^{97}$

Second, these apparent dichotomies create a cognitive dissonance between the internal and external dimensions of the EU non-discrimination legal system. Internally, the 'transformative function' of the principle of non-discrimination lies in its structuring power over daily private relationships within the scope of the Union's competences, that is mainly the labour and consumption markets. ${ }^{98}$ Hence, economic interactions constitute the substance of the right to nondiscrimination. Externally, however, the transformation narrative rests on a rhetoric of liberation from market logics through the creation of a genuine human right. The substantive content of equality, understood as a 'form' and a 'discourse' in the sense of Westen, has therefore changed over time, leading to the coexistence and competition of two overarching, conceptually and ideologically loaded, normative frames. ${ }^{99}$ Is this apparent bipolarity reconcilable? Examining the substance of the new non-discrimination rights granted to EU citizens in the 2000s reveals that understanding the reforms as a radical disruption is fraught with over-simplifications and false dichotomies.

\section{(iii) Equality as a hybrid vehicle for distinct normative projects}

The apparent contradictions in the evolution of the EU equality model make it difficult to provide a sound theoretical account of the principle of equality in the EU. The construction of the EU nondiscrimination system indicates that equality is a deeply hybrid principle of EU law, that cannot be ordered within such a binary structure or entirely subsumed within either a pure economic or a human rights driven rationale. Instead, the principle of non-discrimination and its different 'layers' are a perfect embodiment of the very normative plurality of the EU project itself. Non-discrimination law is in fact the result of three distinct evolutions. The early economic rationale was complemented

95 This is understood as the 'rights [that] are bestowed on humans independently of their belonging to political groups, cultural traditions, religious loyalties, races, but merely by virtue of their membership in the human species'. Luigi Caranti, 'Kant's Theory of Human Rights' in Thomas Cushman (ed.), Handbook of Human Rights (Abingdon: Routledge, 2012). See also Andrew Fagan, 'Philosophical Foundations of Human Rights' in T Cushman (ed.), Handbook of Human Rights (New York: Routledge, 2012) and Ronald Dworkin, 'Rights as Trumps' in Jeremy Waldron (ed.), Theories of Rights (Oxford: Oxford University Press, 1984).

96 See Muir (n 3).

97 Regarding the role of conceptualism in legal reasoning, see Damjan Kukovec, 'Hierarchies as Law' (2014) 21 Columbia Journal of European Law, 1, 144.

${ }^{98}$ Muir (n 3).

${ }^{99}$ See Westen (n 6), 577-8. 
over time by social rights related for instance to social security, pregnancy and maternity. ${ }^{100}$ The spectrum of non-discrimination law was subsequently enlarged to offer fundamental rights to all citizens independently of their participation in the labour market. ${ }^{101}$ However, in lieu of a neat transformation, it is rather a pragmatic accumulation that forms the normative core of nondiscrimination law today. In fact, the 2008 proposal for a Horizontal Directive is described as 'consistent with ... the Lisbon Strategy for Growth and Jobs and the objectives of the EU Social Protection and Social Inclusion Process' as well as being designed 'to further the fundamental rights of citizens, in line with the EU Charter of Fundamental Rights'. ${ }^{102}$ This framing brings together three conceptions of the principle of equality that are presented as a coherent set of goals but are at first sight not entirely congruent. This section explores some of the manifestations and articulations of this hybridity.

The first site of hybridity lies in the economic dimension of the principle of equality. It instrumentally enables what Somek calls the 'transnational substantive economic due process' in a system where different national social models co-exist in the absence of a transnational welfare provider to ensure common standards of social protection. ${ }^{103}$ In doing so, it favours free economic competition. At the same time, non-discrimination rules also restrict economic freedom, 'creeping into European contract law', to guarantee minimum standards of protection of the fundamental human right to equality. ${ }^{104}$ This is a first illustration of the power of symbolic 'reconciliation' of the principle of non-discrimination, in which two apparently contradictory propositions find a ground to co-exist. ${ }^{105}$

The origins of, and justifications for, equality protection also reveal the pragmatic coexistence of two distinct normative projects. While the 'old' grounds - gender and nationality - arose from market-related concerns, the 'new' grounds - race, religion, sexual orientation, age, and disability - have mainly been supported by human rights driven justifications, the valorization of diversity and the promotion of an inclusive society from the outset. This said, the protection from age- and disability-based discrimination, notably, responds explicitly to hybrid concerns. ${ }^{106}$ In fact,

100 See Directive 92/85 of 19 October 1992 on the introduction of measures to encourage improvements in the safety and health at work of pregnant workers and workers who have recently given birth or are breastfeeding [1992] OJ L348/1 and Directive 79/7 of 19 December 1978 on the progressive implementation of the principle of equal treatment for men and women in matters of social security [1978] OJ L6/24.

101 The Race Equality Directive and the Goods and Services Gender Directive create non-discrimination rights for all citizens, notably in their quality of consumers.

In contrast to Reich, I think of the turn towards a fundamental rights rationale in EU non-discrimination law as a third distinctive inflection rather than as a mere broadening of the social dimension of equality norms. See Reich (n 27), 253-4.

102 See Commission (2008) (n 4).

103 Somek (n 23), 47.

104 Reich (n 27), 271.

${ }^{105}$ See Somek (n 23), 3, 10, 11.

106 See Commission, 'Raising employment levels of people with disabilities - the common challenge' (Staff Working Paper) SEC (1998) 1550. According to EU statistics, people with disabilities 'represent one-sixth of the EU's overall working-age population, but their employment rate is comparatively low'. See 'Persons with 
beyond the genuine necessity to protect young and ageing populations and persons living with disabilities, guaranteeing access to labour to large segments of the Union's population instrumentally contributes to the common objective of raising employment rates in Europe. ${ }^{107}$ The same applies in principle to the protection against discrimination based on race, religion and sexual orientation. ${ }^{108}$ The advocacy strategy of the Starting Line Group in fact actively exploited this normative hybridity by framing non-discrimination law as instrumental to the Community's plans to complete the internal market through removing obstacles to the freedom of movement of persons, goods and services and capital. This double framing pragmatically avoided the non-discrimination project being 'entirely locked into the common market logic' by, at the same time, 'appeal[ing] to overall human rights and equality commitments'. ${ }^{109}$ Vice versa, the protection of gender equality is now understood as an end in itself. What we observe is thus a double-sided language, framing two traditionally opposed objectives as actually complementary.

Third, hybridity is also manifest in the differences of material scope of the various directives, as well as their pools of addressees, which give an inflection to one or the other aims of the principle of non-discrimination. When the pool of addressees of non-discrimination rights is limited to workers, the focus of equality seems to be placed on labour market integration. In this perspective, the social rights that non-discrimination law creates for workers as a counterpart of economic integration can be seen as functional or instrumental. On the contrary, when the pool is broader and the law purports to create genuine rights for all, the human rights based understanding of equality seems more evident. Despite a great majority of grounds still being exclusively protected within the realm of the labour market today, partially extending the scope of the law to consumption has allowed some categories of EU citizens, independently of their participation in the labour market, to benefit from some degree of non-discrimination protection in their daily life, for instance when looking for housing, health care or even education in some instances. ${ }^{110}$

Hence, the EU equality model is multidimensional and fulfils the double objective of further integrating the single market and strengthening the set of rights linked to EU citizenship, at times vested with instrumentality, and at times endorses the imperative language of human rights. The symbolic disruption presented by the rights-based reframing of EU non-discrimination law therefore fades when looking beyond artificial discursive dichotomies. The question that arises next is what there is to see beneath the surface of these imaginaries and discourses of equality. The following section takes a closer look at the flesh and bones of the principle of non-discrimination in EU law and its mechanics.

disabilities' (European Commission) available at $<$ http://ec.europa.eu/social/main.jsp? catId=1137> (accessed 22 August 2017).

107 The Lisbon Strategy 2000 stated: 'The employment rate is too low and is characterized by insufficient participation in the labour market by women and older workers' (emphasis added). See Presidency Conclusions, Lisbon European Council (23 and 24 March 2000) available at $<$ http://www.europarl.europa.eu/summits/lis1_en.htm> (accessed 22 August 2017). In addition, although accommodating disability was not mentioned as such as a factor of higher employment the Lisbon Strategy more broadly advocated for 'furthering all aspects of equal opportunities' as part of an 'active employment policy' in the EU. See Presidency Conclusions, Lisbon European Council (23 and 24 March 2000) available at $<$ http://www.europarl.europa.eu/summits/lis1_en.htm> (accessed 22 August 2017).

${ }^{108}$ The case Achbita [2017] (n 21) shows, however, more reservations in this regard on the side of the Court.

109 Niessen and Chopin (2004) (n 85), 99.

${ }^{110}$ Education is only covered by the Race Equality Directive (n 1). 


\section{B. Beyond misleading dichotomies: non-discrimination law as a pragmatic assemblage}

In spite of its normative plurality, the principle of non-discrimination is still characterized by a surprising degree of coherence. This is because, under the specific condition of the Union's liberal mandate, the transformative nature of the principle of equality rests precisely on the accommodation of seemingly opposed frames and rationales. ${ }^{111}$ The following sub-sections deconstruct the rhetorical opposition between market-based and rights-based visions of equality and highlight their actual complementarity through the prism of participation. Looking at the substance of European citizenship reveals the centrality of economic participation and market mechanisms in the specific form and the distribution of the set of equality rights guaranteed by the EU.

\section{(i) Equality through the market: fostering participation through distributive safeguards}

The reason why different normative projects are able to co-exist (albeit not always peacefully) within the same legal principle of non-discrimination is the distributive scope of the EU liberal nondiscrimination model. Participation is the keystone of that system and the market its centre of gravity. Because market participation covers an important part of social interactions, namely work and consumption of goods and services, ensuring non-discrimination in the market is an important step towards equality. This is all the more relevant in the EU context, where market relations constitute a considerable share of the fields regulated by the Union. As Somek shows, in the framework of the Union's liberal mandate '[i]t is difficult to imagine a principle that would be better suited to reconciling solidarity and competitiveness than the principle of equality of opportunity'. ${ }^{112}$ Tellingly, the Lisbon Strategy demands that anti-discrimination law boosts economic efficiency and contemporaneously ensures what EU institutions call 'solidarity'. ${ }^{113}$

In substance, this model of non-discrimination law is based on a range of distributive safeguards and could be described, in the words of Micklitz, as 'access justice'. ${ }^{114}$ It takes the form of a bundle of rights facilitating economic and social participation. ${ }^{115}$ Two core features of this system are its focus on individual participation and its opportunity-based structure. First, it offers an individualistic corrective to unbalanced market opportunities. ${ }^{116}$ Non-discriminatory access to the market ensures minimum economic, and therefore a form of social, participatory safeguards for EU citizens - as workers but also in certain cases as consumers and even at times in education. ${ }^{117}$ This

111 See Somek (n 23), 3-4.

112 Somek (n 23), 3.

113 See Presidency Conclusions, Lisbon European Council (23 and 24 March 2000) available at $<$ http://www.europarl.europa.eu/summits/lis1_en.htm> accessed 22 August 2017.

114 See Hans-Wolfgang Micklitz, 'Social Justice and Access Justice in Private Law' (Working Paper, European University Institute 2011), 21.

115 Ibid, 23.

116 Somek (n 23), 15. See also Christopher McCrudden, 'International and European Norms Regarding National Legal Remedies for Racial Inequality' in Sandra Fredman, Discrimination and Human Rights: The Case of Racism (Oxford: Oxford University Press, 2001).

117 See for instance Münch's argument that the EU polity is a structure of 'acquisitive individualism' where the main focus is 'each individual's access to the market, and the improvement of his or her position in the 
system comes relatively close to what McCrudden calls an individual justice model ${ }^{118}$, in which nondiscrimination is a precondition for individual social participation, a core dimension of equality. ${ }^{119}$

Second, the 'access' model predominantly promotes equality as a process, mainly through symmetry, individual fairness, and the elimination of harmful and illegitimate considerations against certain groups within decision making. The default rule is, as inscribed in the Treaties, 'equal opportunities'. ${ }^{120} \mathrm{EU}$ non-discrimination law in fact mainly focuses on equality of opportunities for disadvantaged citizens to 'rea[p] off the benefits of the market' and participate in the European economy. ${ }^{121}$

Albeit often called a formal equality model, the EU anti-discrimination system goes further than 'blind' or merely 'procedural' formal equality as it provides for more substantive opportunities. It comes closer to Rawls' liberal idea of 'fair equality of opportunity'. ${ }^{122}$ Provisions such as reasonable accommodation and the prohibition of indirect discrimination, to name just a few examples, punctually tilt the balance towards a more substantive form of equality. Article 157(4) TFEU authorizing member States to adopt or maintain positive action measures within certain limits in the name of 'full equality in practice' even lends some outcome-oriented and collective traits to the EU equality model. While its core substance is market participation, some dimensions of the EU equality model like gender mainstreaming obligations foster participation beyond market-related issues. ${ }^{123}$ The substance of equality in the EU context is therefore hybrid and escapes neat theoretical classification.

In spite of the disruptive reframing observable at the symbolic level, EU equality law is deeply reconciliatory. Because the EU non-discrimination model reframed distributive opportunities as rights, it displaced the centre of gravity of the principle of equality from social protection and redistributive justice mechanisms, as traditionally understood in the context of national welfare systems, to economic participatory chances. Through expelling positive socioeconomic rights and redistributive justice outside the field of EU law and pushing them into the domain of national politics, the human rights equality frame could be fitted to the pre-existing

market'. Richard Münch, European Governmentality: The Liberal Drift of Multilevel Governance (Abingdon: Routledge, 2010), 142-3.

${ }^{118}$ McCrudden (n 116), 253-5.

119 See eg Sandra Fredman, 'Substantive equality revisited' (2016) 14 International Journal of Constitutional Law 3712 and Nancy Fraser, 'Social Justice in the Age of Identity Politics: Redistribution, Recognition, Participation’ (Discussion Paper, Wissenschaftszentrum Berlin für Sozialforschung, 1998).

${ }^{120}$ Article 153(1)(i) TFEU mentions 'equality between men and women with regard to labour market opportunities and treatment at work' and Article 157(3) TFEU on equal pay the 'principle of equal opportunities and equal treatment of men and women'.

121 See Micklitz (2011) (n 114), 21. Kennedy speaks of 'weak parties' and Reich of 'vulnerable consumers' but these formulations seem essentializing. See Kennedy (n 94), 66 and Reich (n 27), 270.

122 At the same time, it differs from Rawls' principle in relation to its material and personal scope. The selection of social goods it applies to as well as its pool of addressees are not equivalent. See John Rawls, $A$ Theory of Justice (Oxford: Oxford University Press, 1999).

123 See McCrudden (n 116), 255-9. 
market-based non-discrimination frame within a liberal setting. ${ }^{124}$ Symptomatically, the Union's equality system substituted the vertical redistribution-based dimension that traditionally characterizes national equality politics by reinforcing the horizontal dimension, centred on recognition and distributive interactions. By affecting citizens' relationships at the micro-level, the principle of equality is expected to progressively reshape deeply entrenched behavioural, cultural, and symbolic structures of discrimination in the long run. Restrictions of economic freedom in the name of equality support market integration and growth through limiting inefficient market choices, for instance based on false gender stereotypes or prejudice linked to national or ethnic origin. Switching from a micro to a macro perspective, EU non-discrimination law is meant to modify social relations, and, in a nutshell, the substance of EU citizenship. ${ }^{125}$

As a consequence, even though seen in opposition, the rights-based understanding of non-discrimination law and the market-based rationales come together in a pragmatic assemblage that reveals a surprisingly high degree of complementarity. The mechanism of participatory opportunities serves the double aim of furthering the European economic integration project and advancing European citizenship. This very hybridity, however, entails important frictions and limits. They concern the mechanics of allocation of distributive opportunities as non-discrimination rights and their reach outside the realm of market participation, questions to which we now turn, as well as the coherence of the equality principle, which will be the subject of the last section of this article.

\section{(ii) Equality before the market: providing recognition through an identity-based allocation of non-discrimination rights}

One of the most tangible effects of the framing of the 2000 non-discrimination law reforms through the language of human rights is the reorganization of the mechanics of allocation of nondiscrimination rights around the concept of social identity. ${ }^{126}$ Against the background of what Kennedy calls the 'third globalization', distributive safeguards that used to take the form of welfare programmes at national level were reframed around the category of identity in the EU context. The multiplication of non-discrimination norms and their organization around identity categories in the Treaty of Amsterdam also converged with the liberal human rights frame promoted in international legal and political fora. ${ }^{127}$ The equality paradigm shifted from redistributive and social policies to politics of rights focused on the recognition of social diversity. EU non-discrimination law took on the features of an identity-based framework of protection, allocating equality rights using selected social statuses and memberships as markers of marginalization. Hence, while the substance of nondiscrimination rights is made of distributive opportunities, the recognition paradigm informs the grammar of their allocation.

Framing equality as a fundamental right promotes the ideal of a 'difference-friendly world, where assimilation to majority or dominant cultural norms is no longer the price for equal

124 See Judy Fudge, 'The New Discourse of Labour Rights: From Social to Fundamental Rights?' (2007) 29 Comparative Labor Law and Policy Journal, 1.

125 See Muir (n 3).

126 See Fraser (1998) (119). Often recognition is seen as a politically and economically less costly solution than redistribution, although both are complementary within a 'bivalent' understanding of justice. This distinction is based on Fraser's own distinction between justice as distribution and justice as recognition.

127 Kennedy (n 94). 
respect' ${ }^{128}$ However, the kind of recognition offered by the EU equality model seems more limited. Münch speaks of the 'premarket activation' of structurally disadvantaged individuals so that they can benefit from the removal of market barriers to the same extent as active citizens. ${ }^{129}$ This ex ante policy, he claims, should target 'the collectively shared identity of minorities' which is 'left as the last reason for discrimination' today. ${ }^{130}$ Although this latter affirmation is doubtful in light of the systemic role played by material, economic, and class-based inequalities, Münch points at the limits of the recognition work performed by the EU anti-discrimination system. The accommodation of diversity and social difference is only understood as a precondition for disadvantaged groups to access distributive opportunities. In fact, the recognition secured by EU equality law does not equate a form of 'constitutional multiculturalism that does not protect individuals' rights to freedom but rather the cultural identities of groups'. ${ }^{131}$ Even if the 2000 reforms departed from a mere individualistic concept of equality to punctually provide for an increased understanding of its collective dimension, the recognition of disadvantaged social identities remains intrinsically correlated to individual market access rights. ${ }^{132}$ EU non-discrimination law is therefore 'instrumentalist', as opposed to 'collectivist', as it uses the group as a basis to protect the rights its members possess qua individuals. ${ }^{133}$

In effect, EU anti-discrimination law is marked by this tension between collective and individual recognition. On the one hand, the EU equality system is adversarial: the nondiscrimination rights linked to certain group identities and the social rights deriving from participation in the labour market are mostly individually justiciable and enforceable. ${ }^{134}$ On the other, the ban on indirect discrimination also addresses the collective and systemic nature of inequality as a structural phenomenon often arising from stereotypes, prejudices, and bias. ${ }^{135}$ The

128 Fraser (1998) (119), 1.

129 Münch (n 117), 151. This is opposed to post-market redistribution which guarantees a form of equality closer to equal results.

130 See Münch (117), 142-3.

131 Ibid.

132 Reich (n 27).

133 David Ingram, 'Group rights: A Defense' in Thomas Cushman (ed.), Handbook of Human Rights (Routledge: New York, 2012), 278-9. A collectivist form of group rights would instead grant rights to the group as such, that could potentially limit the group members' individual rights.

134 Different degrees of standing rights granted to certain categories of NGOs, as well as the possibility to aggregate individual claims temper the individual justiciability model in EU non-discrimination law. It has also been argued that individual access to justice does not prevent collective change, notably through strategic litigation and test cases.

See also Fudge (n 124), 46.

135 The CJEU prohibited indirect discrimination based on sex for the first time in C-96/80 J.P. Jenkins $v$ Kingsgate (Clothing Productions) Ltd. [1981] ECR 911, EU:C:1981:80 and then formalized through a unitary definition in Article 2(1) of both the Race Equality Directive 2000/43/EC and the Framework Equality Directive 2000/78/EC (n 1). See Christa Tobler, Limits and Potential of the Concept of Indirect Discrimination (Luxemburg: European Commission, 2008), 23-4 and Christa Tobler, Indirect Discrimination. A Case Study into the Development of the Legal Concept of Indirect Discrimination under EC law (Antwerp: Oxford Intersentia, 2005). 
CJEU for instance showed a willingness to depart from exclusively individualistic equality reasoning by recognizing the importance of structural discrimination. ${ }^{136}$ Displacing the focus from legislation and adjudication to enforcement also highlighted the roots of individual impediments in collective patterns of disadvantage. ${ }^{137}$ For instance, national equality bodies have favoured more collective responses to structural discrimination through awareness-raising campaigns, monitoring work, contextualized policy recommendations, and research at national level. The mandates of equality bodies often even go beyond the minimum standards set by EU law in terms of grounds of discrimination covered and strategies for action, for instance the promotion of positive action

136 See for instance Feryn [2008] (n 64), ACCEPT [2013] (n 65), and even CHEZ [2015] (n 21).

137 In the words of De Búrca, a 'shift away from traditional judicial remedies and towards renewed administrative as well as other more innovative approaches' is to be observed. Gráinne De Búrca, 'The Trajectories of European and American Antidiscrimination Law' (2012) 60 American Journal of Comparative Law, $1,1$.

Traditional top-down legislative and judicial solutions shifted towards more diverse and mixed bottomup alternatives, while the concentration on enforcement through administrative and policy-based or soft law measures increased. The language of the European Commission 2008 Communication reflects this shift on enforcement, which has been made the first priority on the Commission's non-discrimination agenda, along with strengthening policy tools and dialogue with national Member States and civil society. See European Commission (2008) (n 4). This shift is easily observable when looking at the activities of national equality bodies in promoting equality through research, monitoring, legal expertise, and for some of them also litigation. The European Commission's monitoring activities through the European network of legal experts in gender equality and non-discrimination and its financial leverage through selective funding are also part of this shift in methods. By bringing together civil society actors, experts, trade unions, NGOs, and public administrations, the reforms on equality bodies and access to justice has contributed to a more bottom-up approach towards non-discrimination within Member States. The establishment of equality bodies became compulsory for the ground of sex in matters of employment, self-employment, social protection, social advantages, and the supply and consumption of goods and services (Art. 12 of Directive 2004/113/EC, Art. 20 of Directive 2006/54/EC and Art. 11 of Directive 2010/41/EC) and for the ground of race in matters of employment, self-employment, social protection, social advantages, the supply and consumption of goods and services and education (Art. 13 of Directive 2000/43/EC). However, in reality all national equality bodies now cover more grounds than just the required gender and race. There is no harmonization regarding what each equality body covers beyond race and sex, hence the existence of a patchwork at the national level. See the list of all EU equality bodies on Equinet—European Network of Equality Bodies <

http://www.equineteurope.org/-Equinet-Members- > (accessed 19 August 2017).

More recently, the European Pillar of Social Rights proclaimed on 17 November 2017 proposes a non-binding political solution to enhance social protection in the EU, including non-discrimination.

According to Bruno De Witte, 'a distinct multilevel governance regime in the field of antidiscrimination' is under construction, which '[i]n conjunction with the directly enforceable rights contained in the various directives, [...] constitutes a "hybrid model" that seeks to combine the strengths of the rights approach with those of an experimental governance agenda'. De Witte also explains the merging of the equality mandate within broader human rights institutions in the EU (eg the French Défenseur des droits). See Bruno De Witte, 'New Institutions for Promoting Equality in Europe: Legal Transfers, National Bricolage and European Governance' (2012) 60 American Journal of Comparative Law, 73 and Bruno De Witte, 'The crumbling public/private divide: horizontality in European anti-discrimination law' (2009) 13 Citizenship Studies, 515. See also Hans-W Micklitz, 'The reconstruction of the equal treatment litigation', The Politics of Judicial Co-operation in the EU Sunday Trading, Equal Treatment and Good Faith (Cambridge: Cambridge University Press, 2005), 165-291 for a discussion of the activities of the Equal Opportunities Commission in the 1960s and 1970s in the UK which has become a model for today's equality bodies. 
measures. The structural effects of EU equality law however remain limited as its binding core is mainly made up of negative, by contrast to positive, obligations not to discriminate. ${ }^{138}$

The kind of recognition offered by the EU anti-discrimination model presents two further limits. The principle of non-discrimination offers, as a corollary to distributive opportunities, an intersubjective form of recognition. ${ }^{139}$ It aims to secure 'equal respect [for] all participants' in the (labour) market and to 'ensure equal opportunity for achieving social esteem'. ${ }^{140}$ Non-discrimination rules should first and foremost influence the decision-making processes of individual agents. In the long run, however, the idea is that they would reshape 'institutionalized patterns of cultural value' and curb the symbolic systems of inequality and stigmatization that underpin unequal distribution and other material manifestations of discrimination. ${ }^{141}$ The recognition dimension of antidiscrimination law thus aims to not only impact the micro level of individual interactions, but also, in the long term, the macro structural level, through changing 'cultural patterns of interpretation and evaluation' and the social appreciation of status-based differences. ${ }^{142}$ However, it remains unclear whether and how equality as recognition will spread from the micro intersubjective level to the macro structure. Doubts also arise regarding its effects on recognition beyond distributive structures.

The recognition of disadvantaged identity memberships is also limited to some ascriptive categories. The selection of these protected criteria is neither grounded in a clear rationale nor are these categories defined in the directives. ${ }^{143} \mathrm{EU}$ non-discrimination law rather partly absorbed the vulnerability rhetoric of international human rights discourses. It can be considered alluring as a palliative to the deficiencies of distributive mechanisms, but it also risks essentializing the disadvantages linked to certain social divisions. Current EU legislation leaves out other vectors of discrimination such as social, economic or family status, cultural capital or physical appearance, to name just a few examples. ${ }^{144}$ Most Member States as well as the Charter prohibit a larger number of grounds of discrimination. ${ }^{145}$ However, the Union has so far refused to use the Charter as a

${ }^{138}$ One obvious departure from this is the positive obligation for employers to reasonably accommodate employees with disabilities.

139 See Nancy Fraser and Axel Honneth, Redistribution or Recognition? A Political-philosophical Exchange (London: Verso Books, 2004), 36.

140 Ibid.

141 See ibid, 29. See also Iyiola Solanke, Discrimination as Stigma: A Theory of Anti-discrimination Law (Oxford: Hart Publishing, 2017).

142 Fraser and Honneth (n 139), 20.

${ }^{143}$ Identity-based social movements in the 1990s drew attention to the marginalization of certain segments of the population by the prevailing socio-political organization and their demands shaped the very selection of prohibited grounds of discrimination in EU law. On the selection of grounds, see e.g. Erica Howard 'The Case for a Considered Hierarchy of Discrimination Grounds in EU Law' (2006) 13 Maastricht Journal of European and Comparative Law, 4.

${ }^{144}$ For a criticism of the limiting principle of anti-discrimination law, see Solanke (n 141).

145 The Charter includes fifteen protected grounds in its Article 21: language, social origin, genetic features, birth, property, political or other opinion, membership in a national minority, sexual orientation, disability, gender, race and ethnic origin, religion, age, and nationality.

Socio-economic status, for instance, is a prohibited ground of discrimination in Belgium where 'wealth/income' and 'social origin' are protected grounds; in Croatia where 'social origin', 'education', 'property', and 'social status' are protected grounds; in Hungary where 'social origin' and 'financial status' 
touchstone for the application of the general principle of non-discrimination despite its primary law status. ${ }^{146}$ In FOA for instance, the CJEU explicitly refused to extend the number of grounds protected in the directives to the full list contained in Article 21 of the Charter. ${ }^{147}$ Finally, the current equal protection system is inconsistent across its scope ratione materiae and ratione personae so that different protected categories enjoy different degrees of recognition, as the third section of this article will further clarify.

EU non-discrimination law is therefore a hybrid system that accommodates both external pressure for the protection of human rights and the internal diversity of the EU pluralistic legal, social, and economic order. ${ }^{148}$ It solves social conflicts by promoting economic growth, individual freedom and access to the labour and consumption markets through the language of rights and identity. '[R]ecognizing and managing difference' through non-discrimination law is both an instrument of self-legitimization promoting the EU legal regime as a global provider of human rights protection, and a central element of a justice model that is constrained by the liberal imperative of the EU economic project in a time of crisis and austerity. By reconciling these different normative objectives, the anti-discrimination principle however falls short of the ideal of substantive equality promoted by EU institutions, and notably the Commission, in political discourses. ${ }^{149}$

\section{(iii) Equality beyond the market? Non-discrimination vs. equality}

A truly transformative principle should aim to foster autonomy and equality beyond the market and distributive mechanisms, throughout the diversity of social structures. Substantive equality has been given various definitions - the one advanced by Fredman includes four dimensions: political participation, economic participation and the redress of disadvantage, identity recognition and the accommodation of diversity, and finally the end of violence and stigma. ${ }^{150}$ Such a conception of equality goes far beyond the sphere of economic participation and the mere economic agency of citizens. It also exceeds the ambitions of EU anti-discrimination law by far. ${ }^{151}$

are also protected; in Bulgaria where protection includes 'education', 'social status', and 'property status'; in Austria where the Constitution prohibits discrimination based on 'class', 'estate or property', and 'social standing'; in Cyprus where the constitution covers 'social descent', 'wealth', and 'social class'; in Latvia where 'property' and 'social status' are covered; in Malta ('social origin' and 'property'); under related criteria in Romania ('social status' and 'belonging to a disadvantaged group'), Italy and Spain (under 'social condition'), Portugal ('economic situation' and 'social condition'), Slovenia ('social standing' and 'economic situation' and 'education') and Slovakia ('property' and 'social origin'); as well as partly in France where it appears under the prohibited criterion of 'particular vulnerability resulting from a known or apparent economic situation' and in Denmark, Estonia, and Lithuania where it respectively appears under 'social origin' and 'social status'. In addition, 'social origin' and 'property' are also prohibited grounds under the article 21 of the EU Charter as well as under the ECHR.

146 Micklitz (2011) (n 114), 18.

147 FOA [2014], [36]-[37] (n 53). This practice has for instance been endorsed by the Canadian Supreme Court.

${ }^{148}$ Kennedy (n 94), 65.

149 See Dimitry Kochenov, 'Citizenship without Respect: The EU's Troubled Equality Ideal' (2010) Jean Monnet Working Paper 08/10, 10.

150 Fredman, 'Substantive equality revisited' (n 119). 
The evolution of EU law over the last eighteen years nonetheless denotes efforts to push the principle of equality in this direction, beyond labour and consumption in the strictest sense, in domains such as education, social protection, and health care. ${ }^{152}$ Considered broadly, the notion of goods and services could also include the media and advertising, where the prohibition to spread racist prejudices would apply under directive 2000/43/EC. ${ }^{153}$ Given the influence of the media in shaping common social (discriminatory) attitudes, this protection would affect society far beyond market-based interactions and would be an important step towards fighting unfair stereotyping, stigmatization, and the diffusion of discriminatory narratives, through a wide propagation of the principle of non-discrimination in representations, images and cognitive patterns of interpretation and association. ${ }^{154}$ Initiatives in this sense have also been taken beyond EU non-discrimination law. For instance, the Council decision on fighting against racism and xenophobia through criminal sanctions prohibits several forms of breach of equal dignity such as public incitation to, dissemination, condoning or denial of racist and xenophobic hatred and violence. ${ }^{155}$ In the long term, profoundly transforming the symbolic structures underlying and perpetuating discrimination through combating stigmatization and violence can considerably advance equal dignity in the Union. This transformation must go beyond market-derived rights to truly reorganize the interactions of EU citizens at the micro level, as well as cultural patterns of evaluation at the macro level. It must also be accompanied by adequate policy frameworks. Targeted funding provided by the Commission to support policies that foster the conditions necessary for disadvantaged groups to take advantage of the opportunities of EU citizenship is one example of possible measures. ${ }^{156}$

Despite these measures, the impact of the principle of equality beyond market participation remains limited. Paradoxically, the liberal human rights turn pushed some of the fundamental concerns of substantive equality outside the field of non-discrimination law. Considering equality through the lens of Fraser's 'bivalent conception of justice' reveals the

Such a definition would also have to be adapted to the limits of the EU mandate and understood in the context of the relationship between the EU and national legal orders.

152 Some would argue that these could be understood as services available on the free market, but the fact that they are heavily regulated in most member states (both in terms of content and minimum obligations/protection) means that they are not subsumable within what I have so far called the market (ie labour and consumption). Besides, many member states offer a right to health care, and a right to (even an obligation to) education. Mobility could also be considered a fundamental right, as it is protected by the constitutions of some EU member states. In fact, a number of EU regulations, beyond EU non-discrimination law, also specifically protect the rights of eg passengers with disability when travelling.

153 The prohibition of sex discrimination however excludes the media and education, which are explicitly excluded from the scope of the gender directive 2004/113/EC (Art. 3(3)).

154 This is currently explicitly excluded from the prohibition to discriminate based on sex and gender, but the potential consequences of such a prohibition in this regard would be far-reaching (eg advertisement). On stigmatization, see Solanke (n 141).

155 See Article 1(a)(b)(c)(d) in Council Framework Decision (CFD) 2008/913/JHA of 28 November 2008 on combating certain forms and expressions of racism and xenophobia by means of criminal law OJ L 328/55. In particular, it also includes religion along with race, race, colour, and descent or national or ethnic origin as relevant grounds.

156 See, for instance, policy funding policies for the integration of Roma communities, eg the EU Framework for National Roma Integration Strategies 2015. 
complementarity of two elements: redistribution and recognition. ${ }^{157}$ From a substantive equality perspective, the EU non-discrimination framework falls short of both. The transformative reach of the EU non-discrimination principle is limited by the absence of redistributive policies at EU level. In lieu of a supranational welfare system, EU non-discrimination law only provides individually enforceable corrective mechanisms conditional upon economic participation. These mechanisms are criticized for being a palliative to costlier 'hard' measures, such as 'hard-core' social policies granted to disadvantaged groups positively and upstream. ${ }^{158}$ Somek, for example, claims that nondiscrimination law is normatively deficient and 'disguise[s] the Union's lack of ability to address social concerns'. ${ }^{159} \mathrm{He}$ suggests that EU equality legislation is a mere ersatz compensating for the unwillingness to create a European super-welfare state. ${ }^{160}$ Other scholars have also called for the introduction of a 'welfarist objective in non-discrimination law'. ${ }^{161}$

Some authors radically denounce the emptiness of human rights when combined with a neoliberal agenda. ${ }^{162}$ For instance, opponents to the constitutionalization of social rights point out that attaching fundamental status to rights that cannot be guaranteed by liberal policy making is mere illusion. ${ }^{163}$ For the EU, the ensuing critique is that constitutionalizing non-discrimination rights can only give rise to formal and negative equality in the absence of a comprehensive social policy. This circumscribes the EU equality infrastructure to a merely mitigative system unable to defeat historically and structurally embedded inequalities. In light of Young's account, the five faces of oppression - exploitation, marginalization, powerlessness, cultural domination, and violencecannot be overcome exclusively through individual equal treatment, ${ }^{164}$ but instead required collective and positive measures to 'redress past subordination and discrimination' ${ }^{165}$ In this sense, scholars have argued for social inclusion measures such as socio-economic solidarity and social protection, group-based positive action, and a broader duty to accommodate. ${ }^{166}$ The EU non-discrimination

157 See Nancy Fraser, 'From Redistribution to Recognition? Dilemmas of Justice in a 'Postsocialist' Age' Justice Interruptus (Abingdon: Routledge, 1997).

158 Somek (n 23).

159 Ibid, 9.

160 Ibid.

161 See Reich (n 27), 276.

162 See Audrey R. Chapman, Human Rights, Global Health, and Neoliberal Policies (Cambridge: Cambridge University Press, 2016), 83.

163 ME Butt, J Kübert, and CA Schultz, 'Fundamental Social Rights in Europe' (Working paper, European parliament, 1999) available at http://www.europarl.europa.eu/workingpapers/soci/pdf/104_en.pdf (accessed 27 August 2017).

164 These are exploitation, marginalization, powerlessness, cultural domination, and violence. See Iris M. Young, Justice and the Politics of Difference (Princeton, NJ: Princeton University Press, 1990).

165 Sandra Fredman, 'Double trouble: multiple discrimination and EU law' (2005) 2 European Antidiscrimination Law Review, 13, 18. See also Christopher McCrudden, 'Thinking about the discrimination directives' (2005) 1 European Anti-discrimination Law Review, 17.

166 See for instance Fredman's four-tier definition of substantive equality in Fredman, 'Substantive equality revisited' (n 119) and Sandra Fredman, 'Pasts and Futures: EU Equality law' in Alan Bogg, Cathryn Costello, and ACL Davies (eds), Research Handbook of European labour Law (Cheltenham: Edward Elgar Publishing, 
model can thus be criticized for not holding the promise of substantive equality. Human rights pessimists argue that indeed the human rights frame is inadequate and that 'superior projects of emancipation' are needed. ${ }^{167}$

All in all, the EU non-discrimination model participates in what Fraser calls the 'widespread decoupling of the cultural politics of difference from the social politics of equality'. ${ }^{168}$ Symptomatically, the language of substantive equality is almost exclusively found in policies and soft law to the detriment of hard law such as the directives and the Treaty. ${ }^{169}$ As demonstrated by the recent adoption of the European Pillar of Social Rights, the pursuit of a social dimension in the EU was mostly pushed outside the legal field and instead takes the form of non-binding political instruments. It has also proved difficult to reinforce the legal anchor of the social dimensions of the principle of non-discrimination in the EU. ${ }^{170}$ Hence, the transformative reach of the principle of nondiscrimination beyond the market and within the four spheres of substantive equality is limited. The decoupling of redistributive and recognition-based remedies to inequality has enabled the reconfiguration of the principle of non-discrimination as a site of normative 'reconciliation'. ${ }^{171}$ It conditioned the current coupling between distributive opportunities and a fundamental rights approach to social diversity, has reshaped the principle of non-discrimination.

The EU non-discrimination legal corpus can thus be seen as a pragmatic compromise that guarantees a form of citizenship as socio-economic participation, in line with a transnational European proto-society that heavily revolves around market structures and interactions. The form of equality it secures is heavily constrained by the boundaries of the EU mandate. Non-discrimination serves as a bridging principle between different dimensions of European integration. It is a safeguard at supranational level, calling for complementary redistributive measures at national level, the determinacy of which is left in the hands of national governments. ${ }^{172}$ Its transformative reach is, however, discontinuous and inconsistent across the spectrum of grounds and fields regulated, offering an uneven protection against discrimination. ${ }^{173}$ The fluctuating content of the principle of

2016). See also Jayne Hardwick and others, Positive Action Measures. The Experience of Equality Bodies (Brussels: Equinet, 2014).

167 See Dembour (n 83), 138.

168 Fraser (1998) (119), 1.

169 Or the 'European Disability Strategy 2010-2020', EU documents on substantive equality such as European Commission, Tackling Multiple Discrimination: Practices, Policies and Laws (2007) or European Commission, Green paper: Equality and non-discrimination in an enlarged European Union (28 May 2004). In EU law, however, the only directive that mentions substantive equality is Directive 2006/54/EC (recast) in its recital (24), describing 'maternity protection measures as a means to achieve substantive equality'. The other non-discrimination directives are silent on substantive equality. The directives only mention 'full equality in practice' to clarify that EU law does not prevent Member States from adopting positive action measures.

170 For instance the Framework Equality Directive excludes social security and social protection from its scope. See Art. 3(3) and recital (13) of Directive 2000/78/EC. Besides the 2008 Horizontal Directive Proposal shows the difficulty for Member States to agree on a common legal solution.

${ }^{171}$ Somek (n 23), 10-11.

172 Micklitz (2011) (n 114).

173 This will be further detailed in Section IV. 
non-discrimination has translated into lasting hierarchies, which create inequalities within equality. ${ }^{174}$ This differentiated protection is the counterpart of the principle's malleability and capacity of reconciling seemingly opposed normative goals.

\section{Double hierarchies in EU non-discrimination law: a differentiated equality protection}

The previous sections highlighted how dichotomous narratives structure current perceptions of the normative scope of EU non-discrimination law. Instead of disrupting the 'old' economic nondiscrimination principle, however, the constitutional, legislative, and jurisprudential reforms of the EU non-discrimination system have rather reinforced its hybridity. In practice, the reconciling power of the principle of equality translated into a loss of uniformity and consistency. Symptomatic of this hybridity is the twofold hierarchical nature of the principle of equality, de jure and de facto. With the introduction of a non-discrimination framework of protection based on multiple grounds in 2000, one would have expected the protection to extend uniformly across all legislated grounds. Instead, the reforms have durably installed a hierarchy, which limits the transformative reach of the general principle of non-discrimination in the EU.

\section{A. A de jure hierarchy}

The hybridity of the EU non-discrimination system materializes first in the hierarchical nature of its legislative setting. ${ }^{175}$ A de jure hierarchy has been established by the new directives 2000/43/EC, 2000/78/EC, and 2004/113/EC at three levels: the scope, the exceptions, and the effectiveness of secondary legislation. This triple legislative hierarchy arises from the normative complexity created by the multi-ground non-discrimination framework progressively constructed in EU law. In fact, an important diversity hides behind the apparently integrated regime and the seemingly uniform general principle of non-discrimination proclaimed by the CJEU. A tension therefore exists between the efforts to reconcile and integrate the diversity of normative, conceptual, and historical origins of the different grounds protected in a unique framework, on the one hand, and, on the other, the irreducible hybridity and complexity of the different components of that system. ${ }^{176}$

\section{(i) A fragmented scope of protection}

Because the non-discrimination law framework has been constructed in layers, the scope of protection of each ground is not uniform and is the product of political contingencies rather than an emanation of a substantive theory of discrimination. ${ }^{177}$ These inconsistencies in the protection in

174 See McCrudden (n 166), 18 and Päivi Johanna Neuvonen, “"Inequality in equality” in the European Union equality directives: A friend or a foe of more systematized relationships between the protected grounds?' (2015) 15 International Journal of Discrimination and the Law, 222. See Howard (2006) (n 143), 453-4. See also Lisa Waddington and Mark Bell, 'Reflecting on Inequalities in European Equality Law' (2003) 28 European Law Review, 349.

${ }^{175}$ For analysis on the subject, see Howard (2006) (n 143); Sara Benedi Lahuerta, 'Taking EU Equality Law to the Next Level: In Search of Coherence' (2016) European Labour Law Journal, 7(3).

176 See Neuvonen's analysis in terms of 'diversity' and 'integration' in ibid.

177 See Howard (2006) (n 143), 445, 450-6: reasons put forward are 'political pragmatism', the influence of 'international law', 'differences in the character of the grounds', '(hidden) goals pursued by the Member States', 'differences in familiarity with the grounds' and 'differences in type of measures considered necessary'. See also Neuvonen (n 174). 
effect arbitrarily privilege certain identity traits over others. ${ }^{178}$ Sex discrimination has historically been prohibited in the field of employment, where EU non-discrimination law has its roots. Equal pay and equal treatment at work were furthered and completed by directives in the fields of statutory social security, occupational social security schemes, self-employment, pregnant workers, and parental leave from the 1970 s to the 1990 s. ${ }^{179}$ Many of these provisions have been clarified, modernized, and harmonized by Recast Directive 2006/54/EC. ${ }^{180}$ In the meantime, a major extension of gender equality protection took place in 2000 with the enactment of Directive 2004/113/EC prohibiting discrimination in the access to, and supply of, goods and services. ${ }^{181}$ In addition, the principle of gender mainstreaming requires policy makers to consider the impact of policies on gender equality, independently of the area of law concerned.

As for racial and ethnic discrimination, they are prohibited in several areas: in the field of employment, including self-employment, occupation and vocational training; in the area of education; social protection (social security and health care) and social advantages; and in the access to and supply of goods and services available to the public, including housing. These prohibitions are guaranteed by Directive 2000/43/EC, which at present offers the broadest material scope of protection among all grounds. ${ }^{182}$

Both race-based and sex-based equality are very broadly protected, notably in two major areas of life: employment and consumption. However, comparing the scope of the protection they provide reveals a hierarchy. While the Race Equality Directive applies to the field of education, the Gender Equality Directive 2004/113/EC explicitly excludes it, as well as other important areas such as the media and advertising. ${ }^{183}$ The Race Equality Directive being silent on the matter, it could

178 The example provided by Mark Bell is telling in this perspective: following EU legislation, a Muslim woman from North Africa cannot be refused housing on grounds of her ethnic origin but this refusal would not be illegal on grounds of her religion. See M Bell, 'Extending EU Anti-Discrimination Law: Report of an ENAR Ad Hoc Expert Group on Anti-Discrimination Law (Brussels, ENAR, 2008).

179 Council Directive 75/117/EEC of 10 February 1975 on the approximation of the laws of the Member States relating to the application of the principle of equal pay for men and women [1975] OJ L45/19; Directive 76/207/EEC, see (n 19); Council Directive 79/7/EEC of 19 December 1978 on the progressive implementation of the principle of equal treatment for men and women in matters of social security [1978] OJ L6/24. It is important to note that this directive only applies to workers, retired and invalided workers and jobseekers. See Article 2 and Article 3(1).

180 Directive 2006/54/EC (n 1). This directive covers the access to employment, including promotion, and to vocational training, the working conditions, including pay, and occupational social security schemes.

181 Directive 2004/113/EC (n 1).

182 Digging deeper into the negotiation process of the directives, it appears that the Race Equality Directive originally arose from an effort by civil society organizations to ban race and religious discrimination and exclusion in Europe. This interfaith dialogue led to the proposal made by the Starting Line Group, which framed racial and religious discrimination as a single issue as the two grounds significantly overlap. However, when the draft was examined by the Parliament and the Commission, race was accepted as the unique ground for protection, whereas religion was later covered by Directive 2000/78/EC, with a much narrower scope. See Chopin and Niessen (n 11) and Niessen and Chopin (n 85); Lilla Farkas, 'Collective actions under European anti-discrimination law' (2014) 19 European Anti-Discrimination Law Review, 25.

183 See Article 3(3), Directive 2004/113/EC (n 1). 
be interpreted as including the latter within the concept of 'services available to the public'. ${ }^{184}$ Further, while the whole spectrum of protection against racial discrimination is addressed to all citizens, the guarantees offered by the gender equality directives are more differentiated and specifically linked to consumption and work. ${ }^{185}$

All other grounds are protected under the guarantees laid out in Directive 2000/78/EC. The Employment Equality Framework Directive protects religion or belief, disability, age, and sexual orientation in the area of employment, self-employment, and occupation, covering access and promotions, vocational guidance, and (re-)training including practical work experience, working conditions (including pay and dismissals), and memberships of professional organizations. The protection explicitly excludes state-based social benefits such as social protection and social security. ${ }^{186}$ The scope of the directive is therefore more restrictively defined. The fields of consumption of goods and services, social protection as well as education, are left out. This limitation makes the level of protection of these four grounds the narrowest across the entire EU nondiscrimination apparatus.

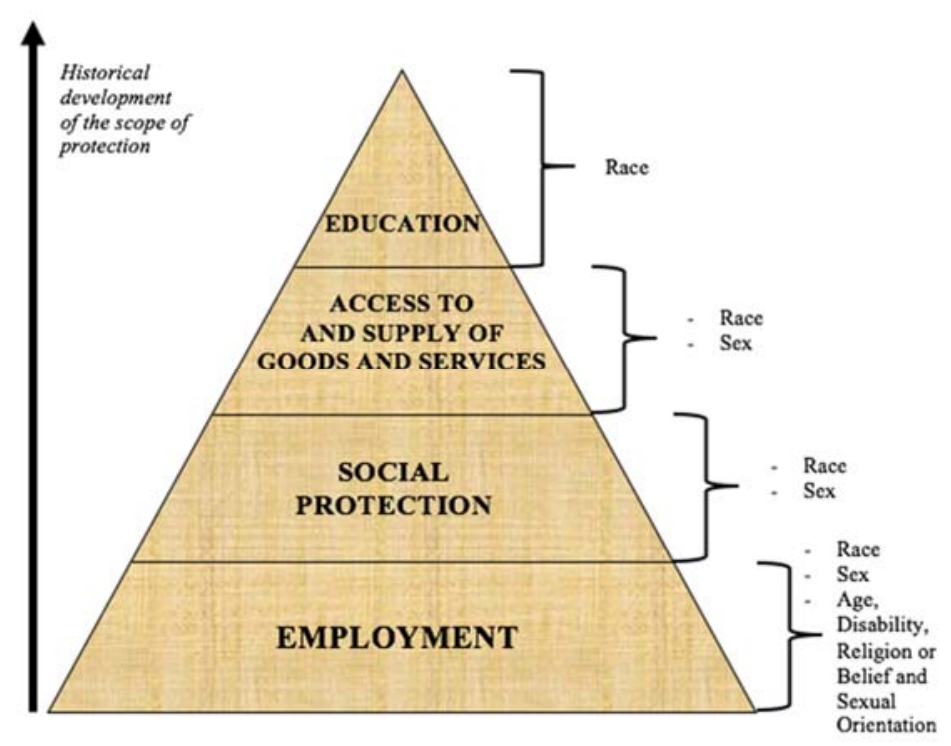

(with the explicit exception of the media and advertising)

\section{Figure 1. EU non-discrimination secondary law: a hierarchy of scopes of protection}

Note: Nationality has been excluded from the classification because it is only protected by Article 18 TFEU, and by secondary law only in the area of free movement of persons by Directive 2004/38/EC.

184 See Directive 2000/43/EC (n 1).

185 This is notably linked to historical reasons. While the sex equality protection was enshrined in the first Treaty as a work-based protection (Article 119 of the Rome Treaty (now article 157 TFEU) on equal pay), Article 13 TEC (now Article 19 TFEU) gave the EU new powers to act against discrimination on a general basis.

Workers are understood in a broad sense as the latter directive covers statutory schemes which provide protection against the risks of sickness, invalidity, old age, accidents at work and occupational diseases, unemployment and social assistance for workers only. See Articles 2 and 3(1) of Directive 79/7/EEC (n 167). 
It is explicitly excluded by non-discrimination directives: Article 3(2) of Directive 2000/78/EC and Directive 2000/43/EC.

Hence, only race, and to a certain extent gender equality, are protected beyond the strict realm of the labour and consumption markets through social protection and/or educational guarantees. ${ }^{187}$ Within these markets, race and gender equality is also protected to a larger extent than the other grounds. These differences translate into a broader horizontal protection of the grounds of race and gender, which touches upon a larger set of daily interactions between EU citizens. Additional evidence of this hierarchical ordering is the creation of equality bodies, which is only mandatory under EU law in the fields of gender and race equality. ${ }^{188}$ The de jure hierarchy thereby extends to the enforcement of non-discrimination law and has materialized into a hierarchy of equality rights in practice. ${ }^{189}$

The de jure hierarchy also manifests itself in the gap between the protection of grounds listed in EU secondary law and the status granted to those set out in primary law. Because the Charter's protection is aligned with the fundamental rights guaranteed by the European Convention on Human Rights, the definition of equality it proposes is broader than in the directives. Article 21 of the Charter features an open-ended list of protected grounds, explicitly mentioning seven grounds that are not included in the directives, namely language, social origin, genetic features, birth, property, political and other opinion, and national minorities. ${ }^{190}$ The nondiscrimination directives remain silent in this regard, offering no binding protection. This limitation also translates into the jurisprudence of the CJEU, which has not yet tackled this discrepancy. ${ }^{191}$ Even though a general principle of non-discrimination has been progressively carved out by the Court in close association with the Charter's Article 21, its scope remains limited to grounds of discrimination explicitly prohibited by EU secondary law. ${ }^{192}$ The selectivity of the protection offered by EU non-discrimination law in comparison with the Charter collides with the universal and

187 Since the status of education varies from one EU Member State to the other, it could be classified as a market good or not (eg public compulsory education).

188 Many equality bodies however have broader mandates.

189 Paul Craig and Gráinne De Búrca, 'Equal Treatment and Non-Discrimination' in Paul Craig and Gráinne De Búrca (eds), EU Law Text, Cases and Materials (Oxford: Oxford University Press, 2015), 911.

190 In fact, Art. 21 states that '[a]ny discrimination based on any ground such as ... shall be prohibited', thus potentially extending the protection to analogous grounds.

191 This discrepancy notably concerns social origin, genetic features, language, political or any other opinion, property, and birth. In addition, membership of a national minority and colour are not explicitly mentioned in Directive 2000/43/EC, even though they can be understood under the concept of race protected by the directive. See Lilla Farkas 'How to Present a Discrimination Claim: Handbook on seeking remedies under the EU Non-discrimination Directives' (European Commission July 2011), 21.

192 FOA [2014], [36] and [39] (n 53). In FOA, the CJEU reckoned that obesity could not count as a protected ground under Article 21 of the Charter, even though the list provided therein is non-exhaustive and could have been interpreted as including the state of health, similarly to the ECtHR case law, for instance in Kiyutin v Russia, Application 2700/10 (ECtHR 2011). In fact, the Court explained that the Charter could not generate new protected grounds despite the open-ended formulation of its Article 21, which protects grounds 'such as ...', and is instead strictly limited to the scope of EU law, ie to the grounds specifically protected by Article 1 of Directive 2000/78/EC in the case of FOA. This is consistent with its previous jurisprudence in Chacón Navas [2006], [56] (n 50), where the CJEU explained that sickness could not constitute a new protected ground by analogy. The same reasoning was applied in Coleman [2008], [46] (n 71). 
categorical nature of equality understood as a human right. Hence, this de jure hierarchy reflects the pragmatic compromise entrenched in the principle of equality which, in the absence of a levelling reform, retains a limited transformative power.

\section{(ii) Legislative exceptions}

The exceptions provided for each ground in the directives further illustrate the hybridity of equality. They accommodate the diversity of normative foundations underlying the protection of each ground within a seemingly uniform and integrated principle and regime. Apart from the general exception of a genuine occupational requirement, which in rare instances authorizes differential treatment, discrimination based on certain grounds is more easily justifiable than on others. ${ }^{193}$ The Framework Equality Directive, for instance, foresees in its Article 3(4) that the non-discrimination provisions on grounds of disability and age may not apply to the armed forces while Article 4(2) provides exceptions for religious institutions, which can impose certain conditions on their employees. Besides, public order concerns can justify discrimination based on all grounds except gender and race. ${ }^{194}$

When it comes to age, Article 6 of Directive 2000/78/EC provides for specific derogations, thus lowering the level of protection against age discrimination in comparison to other grounds. ${ }^{195}$ These exceptions take the form of objective and reasonable 'justifications' of differential treatment, which must serve a legitimate aim. The provision is broad, and the high number of possible justifications has yielded numerous referrals to the CJEU. Usually justifications only apply to indirect, and not direct, discrimination but in the case of differential treatment based on age both types can be justified as Article 6 does not make the distinction. The CJEU is therefore left with important discretion in its interpretation of the justifications. Finally, the protection of national origin is restricted by Directive 2000/43/EC so as to respect Member States' power to control immigration at their borders. Nationality is also excluded from the definition of race and ethnic origin. Some commentators have expressed concern that this exception might entail more problematic consequences than exceptions based on other grounds, for instance serving as a limitation of the protection against racial discrimination for third-country nationals. ${ }^{196}$

193 The exception for genuine and occupational requirements is contained in Article 4 of Directive 2000/43/EC and Directive 2000/78/EC, and in Article 14(2) of Directive 2006/54/EC (n 1).

194 See Article 2(5) of Directive 2000/78/EC (n 1).

195 Recital 25 of Directive 2000/78/EC reads '[t] meeting the aims set out in the Employment Guidelines and encouraging diversity in the workforce. However, differences in treatment in connection with age may be justified under certain circumstances and therefore require specific provisions which may vary in accordance with the situation in Member States. It is therefore essential to distinguish between differences in treatment which are justified, in particular by legitimate employment policy, labour market and vocational training objectives, and discrimination which must be prohibited.' Article 6 deals with the '[j]ustification of differences of treatment on grounds of age'. See $n 1$.

196 Exceptions to the prohibition of age discrimination amount in some context to common accepted standards, such as the legality of setting a minimum age to work. See Evelyn Ellis and Philippa Watson, 'Exceptions to the non-discrimination principle' in Piet Eeckhout and David Anderson (eds), EU AntiDiscrimination Law (Oxford: Oxford University Press, 2012), 401. In addition, questions arise as regards the difference between ethnic origin and nationality. See for instance the case C-668/15 Jyske Finans A/S $v$ Ligebehandlingsnoevnet, acting on behalf of Ismar Huskic [2017] EU:C:2017:278. 
The sum of these different derogations contributes to the fragmentation of the protection against discrimination. They show that in practice a high number of concessions is needed to hold the principle of equality together and secure its reconciling power.

\section{(iii) A differentiated effectiveness}

The differentiated effectiveness of non-discrimination law, which relates both to the source and to the judicial interpretation of the relevant provisions, is a third instance in which the de jure hierarchy manifests itself. ${ }^{197}$ To start with the first, historical enshrinement in the Treaty has placed the various protected grounds differently on the scale of protection. Originally, the prohibition of sex discrimination stems from the Treaty (Article 119 TEC on equal pay, now Article 157 TFEU). This explains why the Court gave horizontal direct effect to the principle of sex equality in the context of employment in Defrenne II although directives cannot be directly horizontally effective. The prohibition of discrimination on grounds of nationality also benefited from a limited but similar horizontal direct effect under certain circumstances. ${ }^{198}$ The Treaty anchor explained the existence of a general principle of non-discrimination on both grounds, which in turn explained the horizontal direct effects. ${ }^{199}$

Section II of this paper clarified how the Court recently revived the debate by deriving a form of horizontal direct effect from the general principle of non-discrimination underpinning Directive 2000/78/EC, this time on grounds of age, with a view to setting aside national legislation. The first occurrence was in Mangold, where the CJEU gave validity to the general principle even though the transposition time of the directive had not yet passed. The CJEU later confirmed the horizontal direct effectiveness of this principle in Kücükdeveci, and more recently in Dansk Industri. ${ }^{200}$ The novelty is twofold. The general principle at stake first generates horizontal direct effects without being a written source of EU law, thus contrasting with the Treaty origin of the same principle for sex and nationality. ${ }^{201}$ Second, it stands out because of its level of abstraction, which

diverges from the level of preciseness and clarity habitually required to generate direct effect. ${ }^{202}$ This recent jurisprudential innovation extends the effectiveness of EU law on further grounds. ${ }^{203}$

197 See Mangold [68] (n 36) and Gráinne De Búrca, A Hierarchy of Equalities (New York: NYU Law 2016).

198 Mirjam De Mol, 'The Novel Approach of the CJEU on the Horizontal Direct Effect of the EU Principle of Non-Discrimination: (Unbridled) Expansionism of EU Law?' (2011) 18 Maastricht Journal of European and Comparative Law, 109, 115-17.

199 In Marshall the CJEU had made clear that no horizontal direct effect ensues from directives. Marshall [1986] (n 33).

200 Dansk Industri [2016] (n 41).

201 De Mol (2011) (n 199), 119. In fact, Article 19 TFEU only states that the Union 'may take appropriate action to combat discrimination', which contrasts with the assertive prohibition of sex- and nationality-based discrimination in the Treaty.

202 See Case-26/62 Van Gend en Loos v Nederlandse Administratie der Belastingen [1963] EU:C:1963:1.

203 One of the limitations of the effectiveness of the general principle could however be its subsidiary nature. Horizontal direct effectiveness has so far indeed only been used as a tool to request the disapplication of national legislation. However, there is no certitude as regards the possibility of its invocation to strike down and substitute national law, thus its ability to directly modify a private legal relationship. The question of its positive validity therefore remains open. 
In view of its recent character, questions arise regarding the material scope of this general principle, its extension to other grounds, and its effectiveness. ${ }^{204} \mathrm{We}$ can in fact wonder whether the Mangold approach will be fully extended to grounds other than age. Following Steve Peers, it would be 'absurd to privilege one particular aspect of the right to non-discrimination over other aspects of that right'. ${ }^{205}$ Yet in Römer, which concerned a vertical relationship, the CJEU gave a sign in this direction. It alluded to the existence of a general principle of non-discrimination on grounds of sexual orientation without it producing direct effects. ${ }^{206}$ Following Römer, the CJEU also recognized a general principle of non-discrimination on grounds of race arising from Article 21 of the Charter in $C H E Z{ }^{207}$ The principle could thus potentially extend to all grounds covered by EU secondary law, expanding the 'new and distinctive substantive discrimination architecture' identified by Claire Kilpatrick in relation to age. ${ }^{208}$ If that proved true, would the horizontal direct effects doctrine be applicable to all grounds protected under the EU non-discrimination regime? ${ }^{209}$ Uncertainties remain as to the effects of the general principle of non-discrimination in light of the ground-specific hierarchies of protection. ${ }^{210}$ This effect would not in any event cover the broad and non-exhaustive list of grounds foreseen by Article 21. The inconsistency of the EU equality corpus of norms might thus affect the very existence and reach of the non-discrimination principle, casting doubt on its general nature.

In light of these innovations, the question of the relationship between the EU human rights order as expressed in the European Charter of Fundamental Rights, and the EU nondiscrimination regime stands out more than ever before. Equality as a human rights principle seems to be developing an existence beyond the EU secondary law non-discrimination apparatus, notably through its effectiveness. Nevertheless, until today the hybridity of non-discrimination law has mainly contributed to the creation of another line of hierarchy within equality in the EU. This de jure hierarchy has given rise to an uneven ground-based protection that can be read as a pragmatic response to the composite normative, conceptual, and historical foundations of the EU nondiscrimination regime.

204 See Claire Kilpatrick, 'The Court of Justice and Labour Law in 2010: A New EU Discrimination Law Architecture' (2011) 40 Industrial Law Journal, 280, 287.

205 Steve Peers, 'Supremacy, equality and human rights: comment on Kücükdeveci (C-555/07)' (2010) 35 European Law Review, 6, 849.

206 C-147/08 Jürgen Römer v Freie und Hansestadt Hamburg EU:C:2011:286, [2011] ECR I-03591, [53][61]. Howard deplores a missed opportunity, while Kilpatrick reads Römer as an explicit extension of the general principle of non-discrimination to the ground of sexual orientation, and an implied extension to all grounds covered by Directive 2000/78/EC. See Erica Howard, 'An opportunity missed? Comment on Römer' (2011) 36 European Law Review, 4589 and Kilpatrick (n 204), 287.

207 CHEZ [2015], [28] and [42] (n 21).

208 According to Kilpatrick, the Court's 'constitutional innovations', observable in the framework of age discrimination case law, in fact serve the goal of developing the 'contours of a new and distinctive substantive discrimination architecture'. See Kilpatrick (n 204), 282-3.

209 See (n. 41).

210 This might also be explainable by the still relatively low amount of litigation on certain grounds, as well as the controversy surrounding the development of the doctrine of horizontal direct effects of general principles, and the de facto horizontal direct effect of directives. 


\section{B. De facto hierarchy and the contested transformative scope of the principle of equality}

Beyond the strict legal framework, praxes around the principle of equality also reveal a de facto hierarchy which testifies to the plurality of existing normative demands in relation to nondiscrimination law in the EU. This second line of hierarchy shows what Westen called 'the fallacy of the independent norm', that is, the protean substance of equality as determined by the agenda of those who invoke it. ${ }^{211}$

\section{(i) The backlash against a more transformative equality principle}

If the non-discrimination principle has undoubtedly become embedded in EU citizenship through its fundamental status, its transformative role remains contested within a broader disagreement over the role of the EU itself. A levelling reform proposed in 2008 by the Commission should have alleviated the limitations linked to the existing de jure hierarchy. ${ }^{212}$ However, the transformative motion slowed down after 2008 due to the stalemate in the negotiations over the so-called 'Horizontal Proposal'. By putting an end to the fragmentation of the EU equality corpus, the proposed directive aimed to enhance the transformative bite of non-discrimination legislation and to enhance its uniformity 'in all areas of life'. ${ }^{213}$ It sought to further regulate the private relationships of EU citizens through extending the horizontal reach of non-discrimination rights on grounds of religion or belief, disability, age, and sexual orientation beyond employment and vocational training, where these grounds are already protected, towards other areas in which an important proportion of discriminatory behaviours occurs. These areas relate to the access to, and supply of, goods and services available to the public including housing, in both the public and the private sectors; but also the field of social protection, including social security and health care; social advantages; and education. In so doing, this ambitious reform intended to align the rules regarding these grounds with those pertaining to the grounds of race and gender, and hence to fill the existing gaps. ${ }^{214}$

Despite an important coalition of transnational NGOs ${ }^{215}$ and the European Parliament supporting the legislative proposal, it faced strong opposition from certain EU Member States in the

${ }^{211}$ Westen (n 6), (580).

212 See (n 2). From the exclusive area of labour, the Proposal sought to extend the protection to social protection, including social security and health care, social advantages, education, and access to and supply of goods and other services which are available to the public, including housing. It is interesting to notice that, even if the directive was adopted, the hierarchy would not completely disappear, as gender equality would still not be protected in education matters, and would remain excluded from the media and advertising. See also Commission staff working document accompanying the proposal for a Council directive on implementing the principle of equal treatment between persons irrespective of religion or belief, disability, age or sexual orientation [2008] SEC(2008) 2180. Even if the rhetoric is about a general principle of non-discrimination in 'all areas of life', the EU has a limited scope of competence (ie labour, including social security and assistance, consumption, and in a more limited way education).

213 See (n 2). European Commission, 'Communication from the Commission to the European Parliament, the Council, the European Economic and Social Committee and the Committee of the Regions-Nondiscrimination and equal opportunities: A renewed commitment' [2008] COM (2008) 0420 final.

214 The willingness to extend the protection also translated into the integration of fundamental rights conventions into the EU legal order. For instance, the EU became party to the UN Convention on the Rights of Persons with Disabilities in 2009 and the Charter of Fundamental Rights became binding the same year.

215 See eg AGE Platform Europe, Amnesty International European Institutions Office, European Disability Forum, European Network Against Racism, Social Platform, The European Network on Religion and Belief, 
Council of Ministers, notably Germany and Poland. ${ }^{216}$ Although they were initially in favour of extending the transformative scope of the non-discrimination principle, Member States have so far failed to reach an agreement, invoking inter alia a too heavy regulatory burden and the risk of contravening the principle of subsidiarity. ${ }^{217}$ EU Member States have also questioned the need for such a directive and opposed the inclusion of access to social protection within the scope of the proposal, privileging non-binding political solutions over law to re-assert the place of the principle of non-discrimination in the EU. ${ }^{218}$ In parallel, market actors insisted on the ensuing costs to business and the risks of increased legal uncertainty. ${ }^{219}$ Despite Juncker's pledge in 2014 that ' $\mathrm{t}$ ] $\mathrm{he}$ AntiDiscrimination Directive w[ould] remain on the table' and his promise to 'persuade the Council to adopt at least the core proposals as soon as possible', fragmentation remains the rule. ${ }^{220}$

In addition, the authority of the European judiciary has been confronted by concerns over national sovereignty, private autonomy, and legal certainty in a tensed political context. Harsh

The European Region of the International Lesbian Gay Bisexual Trans and Intersex Association, The International Lesbian Gay Bisexual Transgender Queer Youth and Student Organisation, 'EU antidiscrimination law: Six years and (still) waiting' (EU Observer, 2 July 2014)

$<$ https://euobserver.com/opinion/124834> (accessed 5 January 2017).

See also AGE Platform Europe; European Disability Forum (EDF), European Network Against Racism (ENAR), European Youth Forum, The European Region of the International Lesbian, Gay, Bisexual, Trans and Intersex Association (ILGA Europe), Social Platform, European Women's Lobby, International Lesbian, Gay, Bisexual, Transgender and Queer Youth and Student Organisation (IGLYO), European Network on Religion and Belief (ENORB), Eurochild, 'Joint Statement. EU equal treatment law: time for Member States to act!' (Brussels, 2014) available at <http://www.age-platform.eu/images/2014-12-

05_Joint_NGO_Statement_before_11_Decembers_EPSCO_Council.pdf $>$ and 'Joint NGO Statement. EU equal treatment law: the time is now!' (Brussels, 2015) available at

$<$ http://www.youthforum.org/assets/2015/06/2015-06-

17 joint_ngo_statement_on_horizontal_directive_before_junes_epsco_council.pdf>.

216 See the negotiations of the Working Party on Social Questions of 24 May 2016 9332/1/16 REV1 on the Proposal for a Council Directive on Implementing the Principle of Equal Treatment between Persons irrespective of Religion or Belief, Disability, Age or Sexual Orientation 2008/0140 (CNS).

217 De Búrca (2012) (n 138), 10. See also Equality for All, 'Joint NGO Statement' (Youth Forum, 16 June 2015) <http://www.youthforum.org/assets/2015/06/2015-06-

17_joint_ngo_statement_on_horizontal_directive_before_junes_epsco_council.pdf $>$ (accessed 23 August 2017).

218 See the newly adopted European Pillar of Social Rights: Jean-Claude Juncker, Statement of President Juncker on the Proclamation of the European Pillar of Social Rights (European Commission: Brussels, 17 November 2017). See also Craig and De Búrca (n 190).

219 See Business Europe, 'Position Paper: Commission Proposal For a Directive on Implementing the Principle of Equal Treatment Between Persons Irrespective of Religion or Belief, Disability, Age, or Sexual Orientation' (BusinessEurope 14 November 2008)

$<$ https://www.businesseurope.eu/sites/buseur/files/media/imported/2008-02385-E.pdf> (accessed 23 August 2017): 'BUSINESSEUROPE is concerned that the proposal will raise costs, enhance red tape and increase legal uncertainty for companies. The proposal also seems counter to the EU's better regulation agenda and will negatively affect the EU's efforts to become more competitive.'

220 Jean-Claude Juncker, A new start for Europe. Opening statement in the European Parliament plenary session (Strasbourg, 15 July 2014) available at $<$ http://europa.eu/rapid/press-release_SPEECH-14567_en.htm> (last consulted on 15 August 2017). 
criticisms have followed the Court's ventures in its interpretation of the new directives and the Charter, especially after the jurisprudential series from Mangold ${ }^{221}$ to Kücükdeveci ${ }^{222}$ and later Dansk Industri. ${ }^{223}$ The backlash was twofold. On the one hand, the autonomy of private parties and their freedom to conduct business were seen as endangered. Critics denounced the Court's activism and efforts to shoehorn the principle of non-discrimination into a rigid fundamental rights principle with 'strong moral status'. ${ }^{224}$ On the other hand, many-and not least the Member States-were concerned about the new repartition of competences ensuing from the constitutionalization of the general principle of non-discrimination. Some scholars also accused the Court of overstepping its competences and appealed to 'Stop the ECJ!', claiming that Mangold was 'only one of many judgments significantly interfering with competences of the member states'. ${ }^{225}$

In the aftermath of the controversial Test-Achats judgment, ${ }^{226}$ the CJEU was similarly criticized for striking down a provision of EU law that had been agreed on by the Member States and thereby overstepping its competences and acting as a de facto legislator. ${ }^{227}$ In the same perspective, the Danish constitutional court set aside the interpretation of the CJEU in its recent resounding judgment in the Dansk Industri case. ${ }^{228}$ This open conflict between the supranational judge and a national court has sparked much criticism towards the CJEU's 'intrusive', 'activist', insensitive, and 'categorical' jurisprudence. ${ }^{229}$ Its extensive interpretation of the non-discrimination principle was

221 See (n 35).

222 See (n 37).

223 Dansk Industri [2016] (n 41).

224 Muir (n 3), 1253.

225 Former German president and president of the German Federal Constitutional Court Roman Herzog and economist Lüder Gerken went so far as to call for a judicial watchdog above the CJEU. Roman Herzog and Lüder Gerken, 'Stoppt den Europäischen Gerichtshof' Frankfurter Allgemeine Zeitung (Frankfurt am Main, 8 September 2008) available at $<$ https://www-faz-biblionet-de.ezproxy.eui.eu/fazportal/document?uid=FAZ FD1200809081915180\&token=83ec99cf-daa9-4212-98bc-

91be3911580a\&p. scr=faz-

archiv\&p.q=Stoppt + den + europ $\% C 3 \% A 4$ ischen + Gerichtshof\&p. source=\&p.max=10\&p.sort=\&p.offset=10\&p ._ts $=1503946332839 \& p . D T \_f r o m=01.08 .2008 \& p . D T \_t o=01.12 .2008 \& p . t i m e F i l t e r T y p e=0>($ accessed 20 February 2017).

226 Test-Achats [2011] (n 54).

227 The controversy revolved around three ideas: (1) that the CJEU overstepped its competences and de facto crafted its own law despite the legislator's will; (2) that the reasoning pertaining to the finding of sex discrimination was flawed; (3) and finally, and mainly coming from mass media and insurance experts, that car or life insurance premiums would increase for women due to the imposition of unisex premiums by the CJEU in Test-Achats. See for instance Joseph Weiler 'Judging the Judges-Apology and Critique' in Maurice Adams and Johan Meeusen (eds) Judging Europe's Judges: The Legitimacy of the Case Law of the European Court of Justice (London: Bloomsbury 2013), 542-5 and Jakob Cornides, 'Three Case Studies on "AntiDiscrimination"', (2012) 23 European Journal of International Law, 2, 517, 529-35 for the first two critiques, and Lisa Bachelor, 'Women could pay $£ 500$ more for car insurance as EU ruling comes into force' (The Guardian, 17 December 2012) available at <https://www.theguardian.com/money/2012/dec/17/women-eucar-insurance-ruling $>$ (accessed 17 August 2017).

228 See Šadl and Mair (n 43).

229 Ibid, 360-2 and 368. 
deemed as going beyond the boundaries of Article 19 TFEU (ex-Article 13 TEC) and breaching the subsidiary character of non-discrimination clauses, thus threatening judicial cooperation for the sake of promoting its own integration-prone agenda.

If the Court currently appears as a less active engine of EU integration in the field of equality, it might be because the backlash against the Court's daring jurisprudential innovations created a willingness on the CJEU's side to avoid further controversy, at least in some discrimination fields. This surely combines with difficulties to consistently inscribe equality within a coherent and uniform normative frame. The polarizing demands stemming from the different understandings of the principle of equality in the EU and the resulting hybridity are symptomatic of a broader disagreement on the role of the Union itself. On the one hand, the ambition to strengthen the EU's mission as a protector of human rights is endorsed by EU institutions willing to transform EU citizenship through fundamental human rights, notably through a broad equality mandate ${ }^{230}$ On the other, national governments advocating for a functional role for the Union within the strict boundaries of subsidiarity support a more limited vision of the EU equality mandate.

\section{(ii) A de facto hierarchy in judicial scrutiny}

In addition to upholding many of the legal justifications made possible by the various directives, the CJEU has also applied different levels of scrutiny to the various protected grounds, leading to differentiated equality guarantees. One way to explain these variations is to look at the rationales underlying the protection of the different grounds. Because each ground needs specific remedies, there cannot be a one-size-fits-all interpretation of the meaning of equality across the entire spectrum of grounds. ${ }^{231}$ Thus, judicial interpretation pragmatically allows the introduction of a minimal de facto scale of scrutiny in order to accommodate the normative plurality of equality within the Union's integrated multi-ground non-discrimination regime.

First, this de facto hierarchy emanates from the implementation by the CJEU of the exceptions and justifications contained in the directives. Because of its specific nature, age might be the most telling example. Age being experienced by all individuals throughout their life, it bears a qualitatively different load than other discrimination grounds. For instance, it is widely accepted that protection from discrimination on the grounds of age should not be absolute (eg minimum age requirements to apply for a job), contrary to an almost absolute protection against racial discrimination within the scope of EU law. ${ }^{232}$ In fact, the experience of age discrimination is an evolving one, and stereotypes linked to age vary widely according to time and space. Age discrimination can take several forms based on whether it concerns young or old age. As a result, age is a ground of discrimination experienced by the majority, instead of a so-called 'minority' identity marker. ${ }^{233}$ At the same time, the long history and widely accepted nature of protection measures

230 This human rights shift is observable in the EU's institutional rhetoric about discrimination from the 2000s onwards. See eg [1] and [4] of the preamble of Directive 2000/78/EC and [2] and [3] of the preamble of Directive 2000/43/EC (n 1).

231 This point has been commented on extensively by non-discrimination specialists. An analysis of the ground-based meaning of equality necessitates single evaluations of the definition of the ground at stake, the nature of the discriminations it faces, what equality means in the context of the ground, and the specific remedies necessary. See ibid.

232 Art. 4 of the race Equality Directive provides for an exception in a case of genuine and determining occupational requirement.

233 See Kennedy (n 94). 
against age discrimination, which are traditionally part of national welfare models, could explain the CJEU's temerity in contradicting certain age-based domestic and private policies, but also at the same time the wider margin of appreciation left to EU Member States in applying legislative exceptions. ${ }^{234}$ Following Kilpatrick, the Court in fact applies a dual standard of scrutiny in age discrimination cases depending on the policy issues concerned. ${ }^{235}$ It follows that the Court adopted a mixed approach to age discrimination, considering differential treatment on grounds of age to sometimes be more justifiable because of its mutable nature and its strong economic bearing, and sometimes to be an easier basis for intervention in national policies compared to grounds that have been more politically disputed, such as religion, in the context of laicity or sexual orientation in the context of survivor's benefits and partnerships. ${ }^{236}$

While some courts, such as the United States Supreme Court, rely on an explicit scale of judicial review, this is not the case at the CJEU. Still, to some extent the level of scrutiny applied implicitly depends on the predominant conceptual and normative underpinning of the legislative protection at stake. Such underpinnings could range, for example, from the genuine protection of fundamental rights to furthering integration of labour markets and increasing employment rates. '[B]alancing seemingly contradicting principles of autonomy and non-discrimination' is a relative task because the balancing exercise performed by the Court depends on the area of law and the ground concerned. ${ }^{237}$ In this balancing task, the rationale underlying the protection of each ground might tip the balance in favour of one or the other principles at stake, depending on the ground protected and its context of invocation, following the overarching goals of the Union. Prechal holds in this sense that 'the different rationales not only influence the interpretation and application of the various concepts of equality and non-discrimination, [but] also influence their mutual relationship'. ${ }^{238}$ Because the CJEU tends to read economic interests in light of fundamental rights and vice versa to craft its equality jurisprudence, the implicit scrutiny scale applied by the CJEU is difficult to read. The irreducible conceptual complexity and normative hybridity of the protection against discrimination makes it difficult to infer the strictness of judicial review from the ground and field concerned.

Some features can still be distinguished. For instance, Prechal describes the review standard for nationality cases as very strict. One can reasonably explain this high standard through the historical nature of the protection and the status of non-discrimination on grounds of nationality as a sine qua non condition for the construction of the Single Market. Gender equality enjoys a

234 This is compared to other grounds the protection of which has been much more societally contested, such as sexual orientation. See Isabelle Chopin and Catharina Germaine, A Comparative Analysis of Nondiscrimination Law in Europe (Brussels: European Network of Legal Experts in Gender Equality and Nondiscrimination, 2016), 31. On a more concrete note, see also the agitation following the so-called 'gay cake' decision: Gareth Lee v Colin McArthur, Karen McArthur and Ashers Baking Company Limited [2016] NICA 39 and subsequently Lee (Respondent) $v$ Ashers Baking Company Ltd and others (Appellants) (Northern Ireland) [2018] UKSC 49.

235 See Kilpatrick (n 204), 291 and in general for an analysis of the dual approach of the Court in its age discrimination case law. It is also interesting to note that Kilpatrick's analysis reveals a selective appropriation of the ECtHR's 'balancing' approach to discrimination. See ibid, 301. This denotes a shift towards the use of a human rights framework in the adjudication of discrimination. See also and Ellis and Watson (n 197), 408-9 and 416 .

236 See e.g. Achbita [2017] (n 21) and Parris [2016] (n 75).

237 Reich (n 27), 256. See Kilpatrick (n 204).

238 Prechal (n 80), 11. 
strong moral status arising from both the functional protection linked to its economic implications for the Single Market, and the more recently acquired fundamental right status linked to Article 19 TFEU. Both the economic and the human rights rationale are relevant for all other grounds but one rationale might prevail over the other, thus inducing variations. Age, for instance, is to be considered within a broadly looser level of scrutiny caused by the numerous justifications mentioned earlier. ${ }^{239}$ Regarding disability, the level of scrutiny is adapted to the duty of reasonable accommodation, which relies on the fundamental right to equality as dignity and inclusion, but might also rely on the economic rationale of including disabled workers in the EU labour force to reduce unemployment rates. This, however, is not the case for religion, which does not benefit from such a duty of reasonable accommodation under EU law, despite its protection within a broader human rights frame in the EU, at the UN, and at the Council of Europe. ${ }^{240}$ In fact, in the absence of a consensus on the place of religion in society within the EU, and in a context of both rising Islamophobia and the politicization of the religious question in European societies (especially as regards Islam), it is unlikely that the CJEU will express strong views on religious accommodation. The recent decision in Achbita in fact indicates restraint in a context of high political sensitivity linked to questions of sovereignty and cultural identity. ${ }^{241}$ Finally, race equality enjoys a high level of scrutiny linked to its historical international status of a fundamental human right, ${ }^{242}$ a rationale which also underpins nondiscrimination based on sexual orientation, although this area has also been caught between concerns about national sovereignty and matters of family law. ${ }^{243}$

Variations in the link between non-discrimination protection and the Charter is a third instance where different levels of judicial scrutiny appear. In some cases like Tyrolean Airways ${ }^{244}$ and Vital Pérez, ${ }^{245}$ the CJEU declined to examine the case in light of the Charter even though the referring courts specifically asked for an interpretation of the non-discrimination provision contained in its Article 21. In another instance, Römer, the Court found the existence of a general principle of

239 This does not exclude some cases where strict scrutiny has prevailed, such as the Age Concern England case, despite the considerable leeway left to the Court under Article 6(1) of the Framework Directive.

240 Arts 2 and 18 of International Covenant on Civil and Political Rights, Arts 9 and 14 ECHR, but also Arts 10 and 21 of the EU Charter. According to Lucy Vickers, however, an indirect duty of reasonable accommodation based on religion might exist under the concept of indirect discrimination, depending on the Court's interpretation of justifications. In fact, an apparently neutral policy that rejects accommodation of religious employees might put them at a particular disadvantage and thus amount to indirect discrimination, depending on the strictness of judicial review. See Lucy Vickers, Religion and Belief Discrimination in Employment-the EU law (European Commission, 2006).

241 See Ronan McCrea, Faith at work: the CJEU's headscarf rulings (EU Law Analysis, 17 March 2017) available at http://eulawanalysis.blogspot.it/2017/03/faith-at-work-cjeus-headscarf-rulings.html (last consulted 16 August 2017). On an additional note, the intersection of gender, race, culture, and religion and the question of female autonomy and patriarchy are completely silenced.

242 See eg the UN Convention on the Elimination of All Forms of Racial Discrimination. See eg Feryn [2008] (n 64) and CHEZ [2015] (n 21). Jyske Finans [2017] (n 196), however, recently restricted the protection from racial discrimination by limiting the definition of the concept of race itself.

243 See for instance ACCEPT [2013] (n 65) for an example of stricter scrutiny, and Parris [2016] (n 75) for an example of looser standard of scrutiny.

244 C-132/11 Tyrolean Airways Tiroler Luftfahrt Gesellschaft mbH contre Betriebsrat Bord der Tyrolean Airways Tiroler Luftfahrt Gesellschaft mbH. EU:C:2012:329, para. 23.

245 Vital Pérez [2014], [25] (n 51). 
equal treatment but did not mention the Charter as one of its sources. Instead, it highlighted its origins in "various international instruments and ... the constitutional traditions common to the Member States'. ${ }^{246}$ The link between the general principle of non-discrimination and the set of fundamental rights promoted by the EU is therefore unsystematic, and even blurry at times, casting doubts on the Court's motivations. On the one hand, the CJEU engages with a rights-driven discourse, where equality is upheld as a fundamental right and a constitutional principle with high moral status. On the other hand, in practice this narrative loses explanatory power when nondiscrimination rights are overridden by competing normative demands such as market-related interests, concerns over private autonomy, subsidiarity, sovereignty, deference to the policy-making branch, and probably also the willingness to avoid controversies. ${ }^{247}$ The normative hybridity of equality makes the different rationales difficult to disentangle in the jurisprudence of the Court, especially when presented as dimensions that are inherent in the principle of equality.

Finally, the context and circumstances of given cases also influence the court's scrutiny. Conflicting social interests meet a different equilibrium across the spectrum of protected grounds, which induces a preference given to one or the other goals pursued by the EU though its equality agenda. Prechal claims, for instance, that in the case of gender a looser test is applied in social security or taxation compared to employment or pay discrimination. ${ }^{248}$ Another illustration is provided by Kilpatrick who explains how the Court applies a looser test to issues of retirement and exit programmes in age discrimination cases. ${ }^{249}$ These contextual variations reflect the influence of the Union's different overarching goals on non-discrimination judicial review. They are neither constant nor straightforwardly readable. All in all, the CJEU's approach is difficult to classify neatly, as confirmed by Prechal, once again, who states that 'while there is a rule of thumb-strict scrutiny wherever one of the prohibited grounds is at stake - the [Court] is rather pragmatic in its approach and not very principled, sometimes contrary to its own declaration of equality and nondiscrimination being fundamental principles or rights' ${ }^{250}$ The transformative reach of nondiscrimination law is thus further limited by the inconsistency of the balancing operated between conflicting concerns, making the EU non-discrimination regime resemble a 'patchwork' ${ }^{251}$ The fact that the normative hybridity subsumed in the Union's integrated multi-ground approach and the conceptual underpinnings of the principle of non-discrimination are not explicit makes equality jurisprudence difficult to read and foresee.

\section{(iii) A de facto hierarchy created by differentiated volumes of preliminary referrals}

246 Römer [2011], [56] and [60] (n 206).

247 One example of this failure is the recent Parris case, where the Court missed the opportunity to identify and redress intersectional discrimination (failing to follow AG Kokott's proposition), thus closing the door to advancing non-discrimination through doctrinal innovations. In this case, the interests of market actors (the providers of pension benefits) as well as state interests (the sovereignty over family law) spoke against the recognition of a discriminatory instance. See Parris [2016] (n 75). The $Z$. case is another missed opportunity for the Court to push the equality agenda forward. See C-363/12 Z. v A Government department and The Board of management of a community school EU:C:2014:159.

248 Ibid.

249 Kilpatrick (n 204).

250 Prechal (n 80), 11

251 Neuvonen (n 174), 225. 
Lastly, the levels of litigation and referrals to the CJEU, which differ based on grounds, timing, and member states of origin, de facto influence the development and the level of protection of the grounds concerned. ${ }^{252}$ Having a look at the references for preliminary ruling brought to the Court since the 2000s gives a good impression of the existence of hierarchies of referrals between the grounds protected. The quantity of references indeed largely varies for each of the different protected grounds. While a high number generally indicate a high level of litigation at the level of EU Member States (all things considered) and is thus a good indicator of the importance of the issue, a lower level indicates a lower willingness, preparedness, sensitivity, or need (eg is the application of the law clear enough?) either on the part of national courts to bring the issue in front of the CJEU, or on the part of public interest lawyers or private parties to litigate cases on the issues concerned. At the same time, the hierarchy in litigation also contributes to different levels of acquaintance with, and reflection about, the protection of different grounds at the CJEU, thus impacting the content of the case law.

It is striking that the first references for religious discrimination have only been made in 2015 and amounted to two cases only up to $2017^{253}$, while Directive 2000/78/EC protecting individuals from religious discrimination was passed in 2000 and transposed at the latest in $2003 .{ }^{254}$ In the same vein, the first references for racial discrimination deemed admissible by the Court have been made only in 2007 and then in 2011, ${ }^{255}$ while the transposition delay of Directive 2000/43/EC was 2003. In contrast, age discrimination has been the object of references for preliminary rulings from national courts much earlier-since 2004.

At the same time, the number of references for age discrimination has surpassed all other grounds, amounting to fifty-five references brought to the CJEU by national courts over the period 2004-15. ${ }^{256}$ It is interesting to note that a majority of decisions regarding age discrimination originate from references for preliminary ruling by German courts (50.9 per cent over the period 2004-15), and to a lesser extent, Austrian and Danish courts (respectively 14.5 per cent and 10.9 per cent). Hypotheses regarding the cause for this could include the ageing structure of their labour markets, the activity of trade unions, or labour market reforms in these countries. Preliminary referrals on other grounds have been far less numerous. This high volume of age-based referrals in fact compares over the same period to twelve references only for disability ${ }^{257}$ and nine for sexual

252 The data gathered under this section has been last updated in January 2017. See Xenidis (n 49), 39.

${ }^{253}$ After that date the amount of litigation increased with further decisions in 2017 and 2018, which however fall out of the period examined in this article.

254 It is not surprising that these references arise from France and Belgium. Preliminary references based on religion: Achbita [2017] (n 21) and Bougnaoui [2017] (n 21).

255 Preliminary references based on race: Feryn [2008] (n 64) referred in 2007 and then CHEZ [2015] (n 21) in 2014 recognized discrimination. Before this, C-328/04 Vajnai [2005] EU:C:2005:596 referred in 2004, C310/10 Ministerul Justiţiei și Libertăţilor Cetăţenești v Ştefan Agafiței and Others [2011] EU:C:2011:467 referred in 2010 and C-394/11 Valeri Hariev Belov contre CHEZ Elektro Balgaria AD e.a. [2013] EU:C:2013:48 referred in 2011 were deemed inadmissible. No discrimination was found in Wardyn (n 48) referred in 2009 and Jyske Finans [2017], (n 196).

256 See Xenidis (n 49). There have been fifty-one references for preliminary ruling concerning the sole ground of age and four references concerning multiple grounds, including age. This amounts to a total of fiftyfive references.

257 Ten references including joined and pending cases have been identified on the sole basis of disability, and two references on the basis of multiple grounds, among which was disability. See Xenidis (n 49). 
orientation ${ }^{258}$ which rank respectively second and third in the de facto hierarchy of references. Only nine references have been made on grounds of race over the same period, four of which have been deemed inadmissible. Besides, when referred, the questions asked of the CJEU as to disability, sexual orientation, and race were more basic than for age. ${ }^{259}$ At the bottom of the hierarchy comes religion, with only two decisions up to $2017 .{ }^{260}$ It seems that the new developments brought by Directive 2004/113/EC to the historical protection of gender equality have also provoked little effusion at the national level, with only two decisions up to 2017 since its transposition deadline ten years before. ${ }^{261}$

Highlighting the presence of a multi-faceted hierarchy within EU non-discrimination law sheds light on the incompleteness of the EU equality project. The fact that this double hierarchy results not only from individual reforms contingent upon political pragmatism, but also from the normative reconciliation operated by the principle of equality, poses problems in terms of the consistency of value-based decision-making and the prioritization of protection. ${ }^{262}$ This observation thus constitutes an incentive for further reflection about ways to bring consistency within the EU equality model, taking into account the conceptual complexities of each ground and the normative hybridity inherent in a general principle of non-discrimination, as well as the Union's overarching aims and the substance of EU citizenship. Far from calling for a kind of 'false uniformity in EU nondiscrimination legislation, the presence of hierarchies demonstrates that the condition for a hybrid but coherent and efficient EU equality model is an explicit and reasoned clarification of the rationales of protection for each ground and of the scope and normative underpinnings of the general principle of non-discrimination. ${ }^{263}$

\section{Conclusion}

While it is attractive to a posteriori reconstruct the expansion of the EU non-discrimination regime as a tipping point in the recent history of the European Union, a critical examination reveals that the

258 Eight references including joined cases have been identified on the sole basis of sexual orientation, and one reference on the basis of multiple grounds, among which was sexual orientation. See Xenidis (n 49).

259 This is likely because of the lower number of legislative exceptions they are subject to but also because of their relatively less developed jurisprudential elaboration. They concerned, for instance, the definitions of the grounds, the exclusion from benefits of same-sex partners, etc. In the case of race, it could also be explained by the political unwillingness to challenge EU competences as granted by Directive 2000/43/EC or that the protection reflects protection already granted by national law.

260 Achbita [2017] (n 21) and Bougnaoui [2017] (n 21). CJEU case law on religion has however been evolving quickly since then. These developments being posterior to the finalization of this article, they cannot however be discussed in detail here.

261 These are the landmark case Test-Achats [2011] (n 54), which has however given rise to a small revolution; and indirectly C-318/13 X (para. 48-9, 51) according to the CURIA search database. No comprehensive search was run on the basis of the existing six directives and relevant Treaty provisions for gender non-discrimination, but the amount of preliminary references is very high, as the legislation has been available for a much longer period of time.

262 See Howard (2006) (n 143). Howard argues that this hierarchy is based on political pragmatism instead of a systemic political reflection and a socially conscious choice.

263 McCrudden (166), 17. McCrudden further insists that the 'pressure for consistency in legal interpretation is potentially problematic because, unless considerable care is taken, necessary differences in the way the different types of discrimination should be treated may be sacrificed to consistency'. 
grand narrative of transformation of EU citizenship through fundamental rights needs to be nuanced. On the one hand, the reforms of the 2000s indisputably made important changes to the equality regime of the Union. A triple motion deepened and broadened the scope of non-discrimination law and anchored it to the realm of human rights law. At the micro-level, the hold of the principle of equality over EU citizens increased through a greater influence on large subsets of interpersonal relationships and social interactions. Ultimately, the principle of non-discrimination should change behaviours, social patterns of choice, and cognitive schemes thus re-modelling social and economic participation at EU level. ${ }^{264}$ At the macro-level, the understanding of equality evolved too. The language of fundamental rights imposed a new framing that gained acceptance in collective imaginaries over the years. In this regard, we should not underestimate the role of discourse in shaping perceptions and reality: thanks to this new legitimizing narrative, the EU could promote itself as a key protector of fundamental rights and find a new impetus for its mandate in a time of crisis. To be sure, the way we understand equality in the framework of EU law was indelibly affected. Proof of this is the broader debate it sparked over the role of the Union.

On the other hand, this discursive strategy rested on a rhetoric of normative disruption which, as this article has showed, is misleading. It constructed a binary opposition between the historical rationale of market integration that underpins the origins of EU non-discrimination law and the human rights 'revolution' brought by the reforms of the 2000s. A closer look at the mechanics of the nondiscrimination regime and the operationalization of the principle of equality shows that this is a false dichotomy. In reality, equality is a hybrid construct that, as Westen predicted, embodies and accommodates different normative demands. ${ }^{265}$ The case of the Union is no exception. This article has shown how equality is a vehicle for distinct normative projects. A prerequisite for overcoming the 'tautology' inherent in the formulation of a 'right to equality' is in fact understanding the very substance of this right, and how it reconciles and accommodates these different demands. ${ }^{266}$ As the present multi-level analysis has shown by examining how equality is constructed, told, constituted and operated in the EU, the reforms of the 2000s reconfigured equality as a space for complementarity between economic competition, market integration and identity-based nondiscrimination rights. Of course, this is not a linear story and other explanatory factors such as political pragmatism, historical and economic contingencies and path-dependency need to be considered when recounting the evolution of the normative foundations of EU equality law. In practice, the hybrid nature of equality bears important consequences. It translates into considerable limits to the scope and reach of enforceable equality rights, as the hierarchies exposed in this article testify. The existing dissonance between a bold political discourse on the centrality of equality in the Union and the current uncertainties on the actual legal content of the principle of nondiscrimination need to be addressed. Despite these limits and the fact that the non-discrimination battle lost its priority on the Member States' political agenda, non-discrimination law could be read - in an optimistic light — as one of the building blocks and safeguards of a form of de minimis EU citizenship. In a period of multi-faceted crisis, the very blurriness of the boundaries and reach of the principle of equality in the EU legal order could prove an opportunity to clarify its moral substance and status. Specifically, the conceptual and normative foundations of equality would need to be clarified and made explicit in relation to each ground of protection for non-discrimination rights to realize their full protective potential and transformative impact. This reflection would give the different actors involved in the construction of the EU non-discrimination regime a sounder methodological and analytical basis to enforce, claim and further develop equality protection.

264 See Muir (n 3).

265 See Westen (n 6), 567-8. 